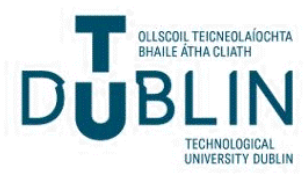

Technological University Dublin

ARROW@TU Dublin

\section{Pilot Scale Pyrolysis of Activated Sludge Waste from Milk Processing Factory}

\author{
Marzena Kwapinska \\ University of Limerick, marzena.kwapinska@ul.ie \\ Alen Horvat \\ University of Limerick \\ Yupeng Liu \\ Technological University Dublin, yupeng.liu@tudublin.ie
}

See next page for additional authors

Follow this and additional works at: https://arrow.tudublin.ie/schfsehart

Part of the Environmental Sciences Commons, and the Food Science Commons

\section{Recommended Citation}

Kwapinska, M., Horvat, A., Liu, Y. et al. Pilot Scale Pyrolysis of Activated Sludge Waste from Milk Processing Factory. Waste Biomass Valor 11, 2887-2903 (2020). DOI: 10.1007/s12649-019-00596-y

This Article is brought to you for free and open access by the School of Food Science and Environmental Health at ARROW@TU Dublin. It has been accepted for inclusion in Articles by an authorized administrator of ARROW@TU

Dublin. For more information, please contact

arrow.admin@tudublin.ie, aisling.coyne@tudublin.ie, gerard.connolly@tudublin.ie.

Funder: Irish State; Science Foundation Ireland

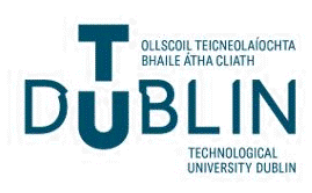


Authors

Marzena Kwapinska, Alen Horvat, Yupeng Liu, and James Leahy

This article is available at ARROW@TU Dublin: https://arrow.tudublin.ie/schfsehart/417 


\title{
Pilot Scale Pyrolysis of Activated Sludge Waste from Milk Processing Factory
}

\author{
M. Kwapinska' ${ }^{1} \cdot$ A. Horvat ${ }^{2} \cdot$ Y. Liü ${ }^{3}$ James J. Leahy ${ }^{2}$
}

Received: 14 September 2018 / Accepted: 21 January 2019 / Published online: 2 February 2019

(c) Springer Nature B.V. 2019

\begin{abstract}
The majority of the sludge from the treatment of wastewater in milk processing plants is land spread. The drawbacks of land spreading include local oversupply due to high transport costs, which results in sludge being spread on lands in the vicinity of the dairy factories. Local oversupply can lead to accumulation of certain substances in soil through annual application over many years. Therefore, in the long term, there is a need for alternative methods to recover energy and nutrients from increasing volumes of sludge generated from dairy processing. Pyrolysis offers a potential alternative to land spreading, which can reduce health and environmental risks, while providing an avenue for the recovery of energy and nutrients. Pyrolysis allows energy recovery in the form of a high calorific value pyrolysis gas and a char which may be used as a soil amendment. In this study pyrolysis of dried dairy sludge was carried out at pilot scale. The results indicate that a dried biological sludge can be successfully pyrolysed and when mixed with wood the resulting char meets European Biochar Certificate criteria regarding carbon content. Most of the initial energy content of the feedstock was retained in the pyrolysis gas prior to cleaning, 53\%, compared to $34.5 \%$ in the char and $1.5 \%$ in the tar. For the pyrolysis gas after cleaning (mainly cracking in presence of air) the initial energy content of the feedstock retained in the gas was only slightly higher than that retained in the char, 39.2\% versus $34.5 \%$, while the tar accounted for $0.8 \%$ of the initial energy content.
\end{abstract}

Keywords Dairy processing sludge $\cdot$ Pilot scale pyrolysis $\cdot$ Pyrolysis gas $\cdot$ Tar $\cdot$ Char $\cdot$ Mass balance

\section{Statement of Novelty}

Biological sludge from wastewater treatment plants in milk processing factories contains valuable nutrients therefore is used in agriculture as a fertiliser. Despite the undoubted fertilizer value, with growing milk production increasing volumes of biological sludge waste will need to be utilized. Therefore we are looking for alternative ways of utilization of its value. Pilot scale pyrolysis of dried biological sludge mixed with wood was investigated. A pyrolysis gas containing mainly $\mathrm{CH}_{4}, \mathrm{CO}, \mathrm{H}_{2}, \mathrm{CO}_{2}$ and $\mathrm{C}_{2} \mathrm{H}_{4}$ was produced with a calorific value of $12-16 \mathrm{MJ} / \mathrm{m}^{3}$, which after conditioning

M. Kwapinska

Marzena.Kwapinska@ul.ie

1 Dairy Processing Technology Centre, University of Limerick, Limerick V94 T9PX, Ireland

2 Department of Chemical Sciences, Bernal Institute, University of Limerick, Limerick V94 T9PX, Ireland

3 Dublin Institute of Technology, Kevin Street, Dublin 8, Ireland was $7 \mathrm{MJ} / \mathrm{m}^{3}$. Concentration of secondary pollutants such as $\mathrm{NH}_{3}, \mathrm{H}_{2} \mathrm{~S}$ and tar was measured. Pyrolysis char retained most nutrients, it is easy to transport long distances and has potential to be used as soil amendment.

\section{Introduction}

Milk processing factories have to deal with the disposal of surplus sludge resulting from dairy effluent treatment plants [1]. The composition of dairy sludge depends on the type of products being manufactured and cleaning process deployed at the plant. In general, there are two main sludge types: (i) chemical sludge which is a mixture of fat, grease, oil and suspended solid particles removed from raw effluent in the wastewater treatment plant together with some proteins and minerals by dissolved air flotation and (ii) biological sludge which is an organic material, containing suspended solids and non-biodegradable pollutants such as heavy metals resulting from biological aerobic, anaerobic or anoxic waste water treatment processes [1-3]. 
According to a survey by Pankakoski at al. [1] the most common use of dairy sludge is disposal to agricultural land. Sludge is sometimes used as a feedstock for anaerobic digestion, however, milk fat is not easily bio-degraded and causes technological issues [4,5]. Smaller amounts of dairy sludge are sometimes used for the production of industrial compost (Germany, Czech Republic); as an animal feed or is dried and incinerated (Belgium, Denmark and Switzerland).

In general, if liquid sludge can be disposed of with reasonable transport costs dewatering, drying or incineration are not used since heat-drying and high temperature process would be restricted to bigger plants and compared to sewage treatment plants, dairy effluent treatment plants are quite small [1].

Dairy sludge contains valuable macro and micro-nutrients, mainly nitrogen $(\mathrm{N})$, phosphorus $(\mathrm{P})$, magnesium $(\mathrm{Mg})$, potassium $(\mathrm{K})$ and calcium $(\mathrm{Ca})$ as well as organic matter $[1,6,7]$. Therefore, recycling of sludge to agricultural land should provide farmers with a fertilizer (source of nutrients) and it is encouraged [8-10]. Yet, there are major differences in the fertilizer value of the sludge from the different kinds of dairy plants, e.g. cheese factories generally have $50 \%$ more phosphorus than fresh milk dairies $[1,6,10]$. An important factor that makes dairy sludge applicable in agriculture is its very low concentration of heavy metals [1, $6,9,10]$. The quantity of heavy metals which accumulate in dairy sludge during the treatment process is much lower than in e.g. sewage sludge [11].

Sludge application to land has to be controlled however to avoid over-fertilization, especially by $\mathrm{N}$, causing leaching of nitrates into the ground water. Additionally, dairy sludge may contain pathogens although Scheltinga [12] reported that the E. coli-numbers were 10-15 times lower than those in domestic sludge. According to current practices in the EU, dairy sludge together with sewage sludge falls under the category of biosolids and legislation or Codes of Good Practice that regulate the disposal of sludge exist in many countries [1]. According to the Irish Code of Good Practice [13], in addition to the concentration of macro and micronutrients, the contents of $\mathrm{Zn}, \mathrm{Cd}, \mathrm{Cu}, \mathrm{Cr}, \mathrm{Hg}, \mathrm{Ni}, \mathrm{Pb}, \mathrm{PCB}$, $\mathrm{PCDD} / \mathrm{F}$ and PHA have to be monitored in biosolids once a year. Biosolids have to be monitored every week for the presence of faecal Coliform and Salmonella species.

There are concerns about environmental risks arising from spreading of biosolids (in particular sewage sludge), which may contain other contaminants or metals which are currently not regulated [14]. More recently, the presence of pathogenic fungi (e.g. Aspergillus sp., Penicillium sp.) and plant-pathogenic genera (Xanthomonas and Xylella of Xanthomonadaceae family) in activated sludge waste from a dairy company in Poland was reported $[15,16]$ leading to the suggestion that microbiological analysis should be performed before field application and if necessary the sludge should be sanitized prior to soil application [16].

In Ireland, the dairy industry accounts for approximately $30 \%$ of Irish agri-food exports, with $80 \%$ of milk products being exported [2]. The Irish government has adopted strategies for significant expansion with the aim to increase milk production by $50 \%$ by 2020 using the average of the outputs from 2007 to 2009 as a baseline. An increase in primary production will inevitably lead to an increase in the generation of processing waste such as sludge from the treatment of wastewater from milk processing plants. In Ireland, the majority of sludge is land spread, e.g. 128,636 tonnes were land spread in 2015 [17]. When dairy sludge is used as a fertiliser $[13,18]$ a strict code of practice must be complied with for the spreading, once a Nutrient Management Plan has been approved by the Irish Environmental Protection Agency.

Despite the undoubted fertilizer value, with growing milk production increasing volumes of biological sludge waste will need to be utilized. Drawbacks of land spreading include local oversupply due to high transport costs, which results in sludge being spread on lands in the vicinity of the dairy factories and weather conditions which could constrain the land spreading. Local oversupply can also lead to the accumulation of certain substances in soil through annual application over many years. Therefore, in the long term, there is a need to find alternative methods to recover energy and nutrients from sludge generated from milk processing plants.

Pyrolysis may be a suitable technology for the treatment of dairy sludge as it can be deployed as a treatment technology at relatively small scale in decentralised locations which are typical of the dairy sector. Pyrolysis offer significant reduction of sludge volume and its sterilisation. In its simplest operation, pyrolysis can be configured with a cracking unit to produce a single gaseous energy carrier and a potentially valuable biochar as a soil nutrient product.

Pyrolysis is the thermal decomposition of organic matter in an inert atmosphere into gaseous, liquid and solid products. Pyrolysis gas contains non-condensable lowmolecular-mass gases such as $\mathrm{H}_{2}, \mathrm{CO}, \mathrm{CH}_{4}, \mathrm{C}_{2} \mathrm{H}_{4}, \mathrm{C}_{2} \mathrm{H}_{6}$ and $\mathrm{CO}_{2}$ as well as condensable volatile compounds i.e. tars, water and water-soluble organics [19]. The solid residue obtained (char), is comprised mainly of carbon and ash. In recent years, pyrolysis has gained increased attention as an alternative disposal method for sewage sludge $[20,21]$. According to a study by Samolada and Zabaniotou [20], pyrolysis could offer an optimal thermochemical treatment option compared to gasification and incineration. It has been suggested that pyrolysis can reduce health and environmental risks from problematic wastes like sewage sludge [22, 23], cotton stalk [24], fruit peels [25], winery waste [26], or oil palm waste [27] while providing an 
avenue for the recovery of energy [28], nutrients in form of biochar/bio-fertilizer [27, 29], or production of highly porous materials to be utilized as adsorbents [25, 30], or catalyst supports [31, 32]. Pyrolysis product yields are affected by the process conditions including temperature and reactor residence time as well as feedstock properties [33]. Slow pyrolysis is generally characterised by relative mild temperatures $\left(350-700{ }^{\circ} \mathrm{C}\right)$ and slow heating rates [20]. One of the main concerns related to all thermal conversion technologies is the release of heavy metals and contaminants such as $\mathrm{NH}_{3}, \mathrm{HCl}, \mathrm{HCN}, \mathrm{H}_{2} \mathrm{~S}$ [34-36]. The low temperature in slow pyrolysis is responsible for low concentrations of heavy metals in the pyrolysis gas, which remain concentrated, fixed, immobilized and potentially stable in the resulting char $[37,38]$. The potential application of all pyrolysis products greatly depends on the presence of various contaminants [39].

Sludge in general, including dairy sludge is a problematic feedstock for pyrolysis because of the high moisture and $\mathrm{N}$ contents (one of the main plant nutrient present in sludge). According to Kim and Parker [40] the energy required for drying was 2-3 times higher than for low temperature pyrolysis $\left(300-500{ }^{\circ} \mathrm{C}\right)$. A recent study showed that drying of sludge requires almost half of the energy present in sewage sludge [41]. A fraction of $\mathrm{N}$ is volatilized under pyrolysis conditions; therefore, pyrolysis gas or flue gas scrubbing is a compulsory post treatment requirement after thermochemical treatment of sludge [41, 42].

A recent study by Marousek et al. [43] demonstrated that it was economically viable to produce biochar from fermentation residue by utilizing waste heat from the cogeneration unit linked to the biogas station. It was reported in the scientific literature that sewage sludge derived carbonaceous pyrolysis products can be used as fertilizer for P-deficient and toxic metal polluted soil [44]. Biochar produced from collagen casing with elevated levels of sodium salt was successfully used for beetroot cultivation [45]. Application of the biochar with sodium led to the transformation of mineral nitrogen into soil organic matter, thereby reducing the nitrate content in the beetroot [46].

Despite its high moisture and $\mathrm{N}$ content, dairy sludge appears to be a better candidate for potential biochar production than sewage sludge since the heavy metal content is typically much lower $[1,6,10,11]$.

This study is part of a project, which investigated the potential of pyrolysis as a conversion technology for sludge from milk processing factories within the frame of a statefunded Dairy Processing Technology Centre. The objective of this work was to determine if pyrolysis of a mixture of biological sludge from dairy processing and wood could provide a gas of sufficient quality for use in a gas engine with the char offering the potential to meet the criteria for European Biochar certification.

\section{Materials and Methods}

\section{Materials}

Sludge from wastewater treatment of an effluent from a milk processing plant in Ireland is the focus of this work. The company produces skim milk powder, whey powder, cheese and base. Sludge after biological treatment processes (activated sludge waste) combined with cationic polyelectrolyte addition was used. When received, the moisture content in the biological sludge (BS) was 93 weight \% (wt\%) ( solids content $7 \%$ ). The BS was dried outdoors in a drying bed (spreading out on polythene film turned over every 3-4 days). After drying, the moisture content was reduced to $17 \mathrm{wt} \%$ (solids content $83 \%$ ). The bulk density of the dried BS was $550 \mathrm{~kg} / \mathrm{m}^{3}$.

Spruce wood chips with a moisture content of $4.7 \mathrm{wt} \%$ and the bulk density of $197 \mathrm{~kg} / \mathrm{m}^{3}$ were sourced locally in county Tipperary (Ireland). The dried BS was mixed with the wood chips in a 50/50 ratio by weight. The proximate and ultimate properties of BS, wood and the mixture are presented in Table 1.

\section{Pyrolysis Experiments}

The experimental tests were carried out in a pilot scale facility used predominantly for pyrolysis of wood chips at Premier Green Energy, Thurles, Ireland. The pilot facility consists of four main sections: feeding system, pyrolysis reactor with char and gas separation section, gas conditioning section and a gas engine or flare. The feeding system comprises of two hoppers, a series of augers and interlocking

Table 1 Proximate and ultimate properties of biological sludge-BS, wood and mixture of BS with wood

\begin{tabular}{lrll}
\hline Properties (wt $\%)$ & BS & Wood & $\begin{array}{l}\text { BS/Wood } \\
50 / 50\end{array}$ \\
\hline Moisture, ar. & 93.16 & - & - \\
Moisture, after drying & 17.24 & 4.72 & 10.97 \\
Ash content, db. & 31.79 & 0.50 & 14.69 \\
Volatile matter, db. & 59.73 & 84.13 & 70.70 \\
Fixed carbon, db. & 8.51 & 15.37 & 14.61 \\
LHV (MJ/kg) & 14.31 & 18.59 & 16.36 \\
C, db. & 35.92 & 50.77 & 42.96 \\
H, db. & 5.59 & 6.60 & 6.09 \\
N, db. & 5.76 & 0.21 & 3.04 \\
S, db. & 0.85 & 0.02 & 0.40 \\
Cl, db. & 0.18 & 0.005 & 0.11 \\
O, db. (by difference) & 19.90 & 41.9 & 32.71 \\
\hline
\end{tabular}

$a r$. as received basis, $d b$. dry basis 
gate valves to ensure uniform input of feedstock with minimal air entering into the pyrolysis reactor. In order to prevent pyrolysis of the feedstock prior to its entry into the reactor the feeding pipe is cooled using a water jacket. The pyrolysis reactor is a stationary muffle furnace with a refractory lined SS253 MA steel rotating retort. The pyrolysis temperature was the average temperature measured at the entrance and the outlet of the reaction chamber (retort). At the beginning of each test, before the feedstock was fed into the conversion chamber, an oxygen deficient environment was created by purging the retort with nitrogen until the oxygen content was below 3 vol\%. The feedstock residence time in the retort was about $10 \mathrm{~min}$ while the residence time of the gas was about $7 \mathrm{~s}$. The majority of the char leaving the reactor was gravity separated and collected in a storage vessel. Fine char particles were separated from the pyrolysis gas in a hot cyclone. Subsequently the gas was ducted into a cracking reactor, where it was mixed with air pre-heated to about $400-450{ }^{\circ} \mathrm{C}$ in the recuperator. The residence time of the gas in the cracking reactor was about $3 \mathrm{~s}$. The gas leaving the cracker was ducted into a recuperator to reduce its temperature to $150 \pm 50{ }^{\circ} \mathrm{C}$ prior to wet gas scrubbing while preheating the air for reaction. The cooled gas was further conditioned in a water scrubber, activated carbon filter, de-humidifier and finally was reheated to $30-45{ }^{\circ} \mathrm{C}$ before being sent to the gas engine. The pilot plant operates at slightly negative pressure; the pyrolysis gas was extracted from the system using a gas booster. A schematic diagram of the experimental facility with sampling points is shown in Fig. 1. Operating process conditions for the pyrolysis experiments for the BS/wood mixture are presented in Table 2. For each experiment the following physical properties were measured: mass of feedstock fed in, mass of char produced, volumetric flow of pyrolysis gas and air for the cracking reactor. The gas composition was measured online at the 3rd sampling port while off-line gas samples were collected in Tedlar bags at the 1st and 2nd sampling ports. Samples of gas were taken at all sampling points for determination of
Table 2 Process conditions for pyrolysis experiments at a steady state operation

\begin{tabular}{lllll}
\hline & $\begin{array}{l}\text { Feed- } \\
\text { ing rate } \\
(\mathrm{kg} / \mathrm{h})\end{array}$ & $\begin{array}{l}\text { Pyrolysis } \\
\text { temperature } \\
\left({ }^{\circ} \mathrm{C}\right)\end{array}$ & $\begin{array}{l}\text { Cracking reac- } \\
\text { tor temperature } \\
\left({ }^{\circ} \mathrm{C}\right)\end{array}$ & $\begin{array}{l}\text { Flow rate of } \\
\text { air for cracking } \\
\left(\mathrm{Nm}^{3} / \mathrm{h}\right)\end{array}$ \\
\hline Test 1 & 77 & 770 & $870-900$ & 37.2 \\
Test 2 & 90 & 700 & 890 & 33.6 \\
Test 3 & 78 & 700 & 900 & 26.4 \\
Test 4 & 84 & 770 & 800 & 30.0 \\
\hline
\end{tabular}

solid phase adsorption (SPA) tar content, moisture content and $\mathrm{NH}_{3}$.

\section{Analytical Techniques}

The pyrolysis gas composition was determined by gas chromatography using an Agilent Micro-GC 3000 equipped with three modules, each with a thermal conductivity detector configured for the detection of permanent gases and light hydrocarbons. Module A was fitted with a Plot-U column of $30 \mu \mathrm{m} / 32 \mu \mathrm{m} / 8 \mathrm{~m}$ and Pre Col: PLOTQ $10 \mu \mathrm{m} / 320 \mu \mathrm{m} / 1 \mathrm{~m}$, using helium as the carrier gas, to separate and detect $\mathrm{CH}_{4}$, $\mathrm{CO}_{2}, \mathrm{C}_{2} \mathrm{H}_{4}, \mathrm{C}_{2} \mathrm{H}_{6}, \mathrm{C}_{2} \mathrm{H}_{2}, \mathrm{H}_{2} \mathrm{~S}$. The injector temperature was $80^{\circ} \mathrm{C}$ and the column temperature $84^{\circ} \mathrm{C}$. Module $\mathrm{C}$ was fitted with Molsieve $12 \mu \mathrm{m} / 320 \mu \mathrm{m} / 10 \mathrm{~m}$ and Pro Col PLOTU $30 \mu \mathrm{m} / 320 \mu \mathrm{m} / 3 \mathrm{~m}$ columns, and used argon as the carrier gas, to separate and detect $\mathrm{H}_{2}, \mathrm{O}_{2}, \mathrm{~N}_{2}, \mathrm{CH}_{4}$ and $\mathrm{CO}$. The injector temperature was $90^{\circ} \mathrm{C}$ and the column temperature $145^{\circ} \mathrm{C}$. Module $\mathrm{B}$ was not used during this study.

The $\mathrm{NH}_{3}$ content in the pyrolysis gas was measured by means of an off-line quantification procedure, which was applied to the retained amounts of ammonia in absorbing solutions. The $\mathrm{NH}_{3}$ sampling train consisted of four impingers arranged in series. The impingers were filled with $0.8 \mathrm{~L}$ of saturated boric acid solution for Test 2 and 3 while for Test 4 a $0.05 \mathrm{M} \mathrm{H}_{2} \mathrm{SO}_{4}$ solution was used. The final impinger in the train was filled with cotton wool in order to

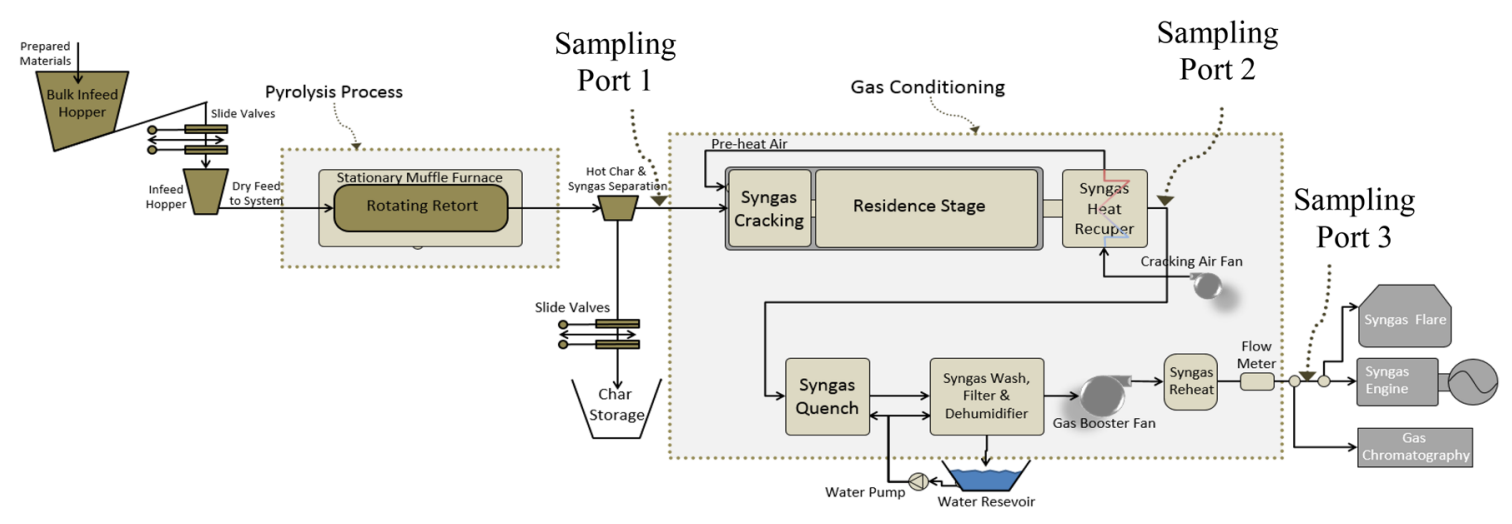

Fig. 1 Schematic diagram of pilot scale facility 
remove remaining liquids. A vacuum pump was used to pull the gas through the sampling train. The amount of ammonia was determined by back titration with standardised $0.10 \mathrm{M}$ $\mathrm{HCl}$. The sampling ports and tubes were insulated in order to avoid water condensation.

Tar samples were taken at three sampling ports. Sampling port 1 was located between the pyrolysis reactor and the thermal tar cracking unit, sampling port 2 was located immediately after the thermal tar cracking unit, and sampling port 3 was just before the internal combustion engine (Fig. 3). The tar sampling ports were designed for the standard solid phase adsorption (SPA) sampling protocol. $100 \mathrm{~mL}$ of the pyrolysis gas was withdrawn by an SPA device comprised of a stainless-steel needle, pre-packed Discovery ${ }^{\circledR}$ DSC-NH ${ }_{2}$ SPE cartridge containing aminopropylsilane sorbent, and a $100 \mathrm{~mL}$ gas tight syringe. Tar compounds were extracted from the sorbent with $3 \times 600 \mu \mathrm{L}$ of dichloromethane, while tert-butylcyclohexane was added as an internal standard to each extracted tar solution. A gas chromatograph fitted with flame ionization detection (GC-FID) (Thermo Scientific, Model Trace 1310) was employed in order to quantify the tar compounds between 2-methylpropanenitrile and indeno[1,2,3-cd] pyrene. A gas chromatograph coupled with a mass selective detector (GC-MSD) (Agilent 7890A GC and MSD 5975C) was used for identification of the most abundant tar compounds. The calibration of the GC-FID used a single quantitation curve prepared using 5 known concentrations of naphthalene/tert-butylcyclohexane. This simplified calibration, based on a single quantitation curve offers a significant advantage, in terms of speed and quantitation of complex materials such as tar however, it can result in up to $35 \%$ relative expanded uncertainty within the reported results for the GC-FID based measurement system [47]. Total tar yields are referred to as total gas chromatography detectable tar and expressed on a volumetric basis as $\mathrm{g}_{\text {total tar }} / \mathrm{Nm}_{\text {dry gas }}^{3}$ or $\mathrm{g}_{\text {total tar }} / \mathrm{Nm}^{3}$ of dry and $\mathrm{N}_{2}$ free gas for the tar in the gas sampled at port 1.

Moisture content was determined using an adsorption method. $100 \mathrm{~mL}$ of hot gas was drawn through $1.0 \mathrm{~g}$ of phosphorus pentoxide $\left(\mathrm{P}_{2} \mathrm{O}_{5}\right)$ at $50 \mathrm{~mL} / \mathrm{min}$ allowing the gas to cool to room temperature (about $25^{\circ} \mathrm{C}$ ) and achieve complete adsorption. The moisture content was calculated as the mass gained after adsorption. Although most of the tar compounds condensed or were adsorbed, the mass of moisture in the product gas was an order of magnitude higher than tar (Tables 5, 6) which makes this method sufficiently accurate for the intended purpose.

Analysis of the proximate and ultimate properties of the dried sludge, wood and the pyrolysis char were carried out by Celignis Analytical, Ireland. The moisture content was analysed according to BS EN 14774-1:2009, the ash content according to BS EN 15403:2011 and the volatile matter content according to the BS EN 15402:2011 standard procedure.
The elemental composition (C, H, N and $\mathrm{S}$ ) was determined using a Vario EL cube elemental analyser with the $\mathrm{Cl}$ content determined according to BS EN 15408:2011 and oxygen content calculated by the difference. The proximate and ultimate properties are expressed as weight $\%$ (wt $\%)$. The higher heating value (HHV) was measured with a Parr 6300 isoperibolic calorimeter and the corresponding lower heating value (LHV) was calculated.

Thermogravimetric analysis (TGA) was performed in a TA Q500 instrument. Approximately $14 \mathrm{mg}$ of dried, ground and sieved to particle size below $50 \mu \mathrm{m}$ biological sludge was placed into an alumina pan without a lid and heated from ambient temperature to $900{ }^{\circ} \mathrm{C}$ at $20^{\circ} \mathrm{C} /$ min under a nitrogen purge flow of $20 \mathrm{~cm}^{3} / \mathrm{min}$. The same test was performed for $4 \mathrm{mg}$ of dried, ground and sieved spruce wood.

Inorganic constituents were measured using inductively coupled plasma optical emission spectrometry (Agilent 5100 ICP-OES fitted with an SPS4 auto-sampler) after nitric acid and hydrogen peroxide and hydrofluoric acid $\left(\mathrm{HNO}_{3}-\mathrm{H}_{2} \mathrm{O}_{2}-\mathrm{HF}\right)$ digestion in a microwave oven according to BS EN 15290:2011. Before digestion, BS and wood were ashed at $550{ }^{\circ} \mathrm{C}$.

\section{Results and Discussion}

\section{Properties of Biological Sludge, Wood and the Mixture}

In Table 1 the properties of the dried BS, spruce wood and the mixture are presented. In the BS tested, a volatile matter content of $60 \mathrm{wt} \%$ and an ash content of $32 \mathrm{wt} \%$ were observed (dry basis), indicating that during high temperature decomposition, most of the organic content of the dried sludge formed vapour-phase products (non-condensable permanent gases and condensable compounds) but also significant amounts remained in the form of solid residue. A high volatile matter is advantageous if the pyrolysis gas is a desirable product. A fixed carbon content of $8.5 \mathrm{wt} \%$ indicates the amount of unconverted carbon which potentially will remain in the char after pyrolysis. The nitrogen content was high at $5.8 \mathrm{wt} \%$ which is one of the typical characteristics of dairy sludge resulting from biological and chemical treatment of defatted effluent [1]. A sulphur content of $0.8 \mathrm{wt} \%$ was observed while the chlorine content was much lower at $0.2 \mathrm{wt} \%$.

The thermogravimetric (TG) curves (weight loss) obtained during the programed heating experiment for the BS and wood in an inert atmosphere are shown in Figs. 2 and 3. It can be seen from the thermogram in Fig. 2 that the main devolatilisation (pyrolysis) process occurred at temperatures below $700{ }^{\circ} \mathrm{C}$ with $65 \%$ mass reduction observed for BS followed by a further gradual decrease in sample mass up 


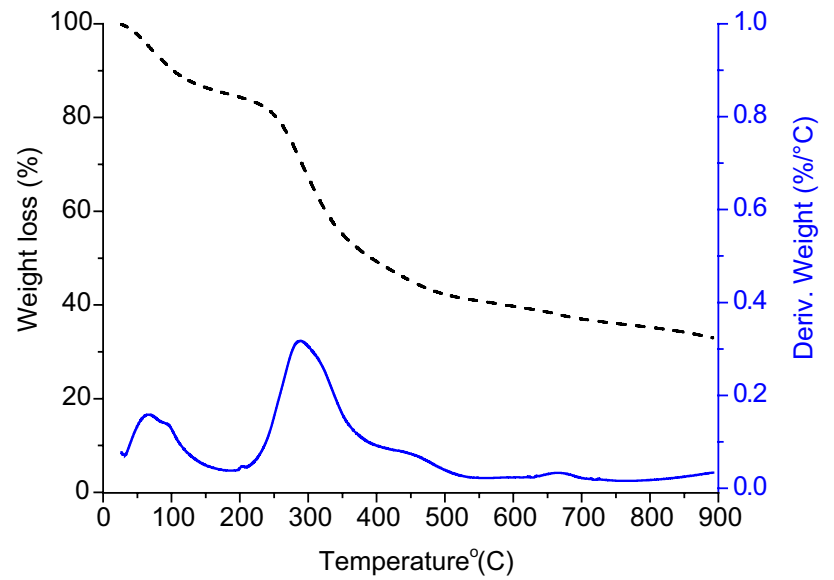

Fig. 2 TG curves for dried biological sludge

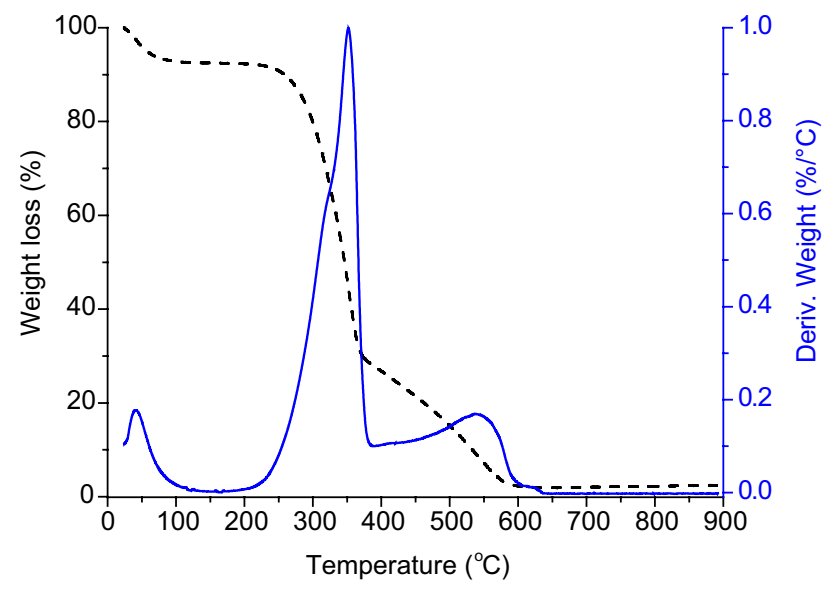

Fig. 3 TG curves for dried spruce wood

to the final temperature $\left(900^{\circ} \mathrm{C}\right)$. But for sample of wood at this temperature $95 \%$ mass reduction was observed (Fig. 3).

The differential thermogravimetry (DTG) curves, which represent the rate of mass loss, reveal differences between the chemical nature of the BS and wood samples tested. The peaks in Figs. 2 and 3 show the decomposition of specific components occurring at different temperatures because of intrinsic differences in the structure of these constituents. It was observed by Sunooj et al. [48] that the peak maximum temperature for cow milk protein decomposition occurs at $327^{\circ} \mathrm{C}$ while that for milk fat is at $413^{\circ} \mathrm{C}$. Whereas Mocanu et al. [49] reported that decomposition of casein, the main protein in milk, starts at temperatures above $176{ }^{\circ} \mathrm{C}$ and proceeds in three stages up to $610{ }^{\circ} \mathrm{C}$ with the peak maximum degradation at $310^{\circ} \mathrm{C}$. In Fig. 2 the first peak at about $105^{\circ} \mathrm{C}$ originates from evaporation of moisture and volatile organic acids. The second peak at $289{ }^{\circ} \mathrm{C}$ probably corresponds to the decomposition of protein. The small peak within the temperature range from 400 to $500{ }^{\circ} \mathrm{C}$ is most likely arising from the decomposition of fat. The major fat component in dairy factory waste waters is triglyceride (98\%) with smaller amounts of phospholipids and sterols [5]. The BS contains high amounts of volatile inorganic elements, such as $\mathrm{S}, \mathrm{K}$ and $\mathrm{Na}[6,7]$. The last small peak observed between 600 and $700{ }^{\circ} \mathrm{C}$ may be caused by the release of these inorganic compounds $[22,35]$.

The first peak (below $100{ }^{\circ} \mathrm{C}$ ), in the DTG curve of spruce wood, corresponds to water loss. The large second peak between 200 and $400{ }^{\circ} \mathrm{C}$ represents the decomposition of both hemi-cellulose and cellulose. According to Yang et al. [50] hemi-cellulose decomposes mainly at $220-315^{\circ} \mathrm{C}$, cellulose at $315-400{ }^{\circ} \mathrm{C}$, while lignin decomposes over a wide temperature range from 160 to $900{ }^{\circ} \mathrm{C}$. However, according to Deng et al. [51] hemi-cellulose breaks down at temperatures ranging from 200 to $250{ }^{\circ} \mathrm{C}$, and cellulose between 240 and $350^{\circ} \mathrm{C}$, with lignin decomposing between 280 and $500{ }^{\circ} \mathrm{C}$. For the spruce wood, the peak for hemi-cellulose is partially merged with that of cellulose. A small bump on the larger peak in the DTG curve visible at about $316^{\circ} \mathrm{C}$ is suggestive of the thermal decomposition of hemi-cellulose, with the peak at $351{ }^{\circ} \mathrm{C}$ representing cellulose decomposition. The peak appearing at $539^{\circ} \mathrm{C}$ most likely correspond to the lignin decomposition.

The content of the major and minor elements in the inorganic matter of BS and wood is reported in Table 3 where it can be seen that the silica content was the most abundant element for both materials. The main nutrients found in BS were phosphorus, calcium, potassium, and magnesium. The heavy metal content was generally very low in the BS and only trace amounts were observed in the wood. Among all the heavy metals analysed, the content of $\mathrm{Ba}, \mathrm{Mn}$ and $\mathrm{Zn}$ were the highest in BS in the range from 100 to $200 \mathrm{mg} / \mathrm{kg}$ of dry matter. The $\mathrm{Zn}$ probably originates from the galvanized water pipe system [1].

The content of $\mathrm{P}, \mathrm{Ca}, \mathrm{K}, \mathrm{Na}$ in $\mathrm{BS}$ is in the range reported by Dabrowski $[7,10]$ who tested dairy sludge from seven milk processing plants and found following concentration of $\mathrm{P}\left(1.9-48.8 \mathrm{~g} / \mathrm{kg}_{\text {dry matter }}\right), \mathrm{Ca}\left(18.0-73.3 \mathrm{~g} / \mathrm{kg}_{\text {dry matter }}\right)$, $\mathrm{K}\left(9.1-9.7 \mathrm{~g} / \mathrm{kg}_{\text {dry matter }}\right)$ and $\mathrm{Na}\left(3.6-18.4 \mathrm{~g} / \mathrm{kg}_{\text {dry matter }}\right)$. It is worth nothing that high the P content of 36.0 and $48.8 \mathrm{~g} /$ $\mathrm{kg}_{\text {dry matter }}$ was found only in two dairy sludge samples [10]. The content of $\mathrm{Mg}$ in BS is lower than that reported in [7, 10 ], 0.8 versus $1.2-6.8 \mathrm{~g} / \mathrm{kg}_{\text {dry matter }}$ The content of heavy metals $\mathrm{Cd}, \mathrm{Cr}, \mathrm{Cu}, \mathrm{Hg}, \mathrm{Ni}, \mathrm{Pb}$ and $\mathrm{Zn}$ is well with the range reported by Dabrowski [10] and by López-Mosquera et al. [9].

When pyrolysing a feedstock, one needs to find a potential application/use for all the products. In this project, the main focus was on the pyrolysis gas which could either be burned directly in a boiler or after cleaning could be used in a gas engine to produce electricity and heat. The high amounts of nitrogen, sulphur and chlorine in the BS bring considerable 
Table 3 Content of major and minor ash forming elements in the BS and wood

\begin{tabular}{|c|c|c|}
\hline Element & $\begin{array}{l}\text { Biological sludge }(\mathrm{mg} / \\
\mathrm{kg}_{\text {dry matter }}\end{array}$ & $\begin{array}{l}\text { Spruce } \\
\text { wood (mg/ } \\
\mathrm{kg}_{\text {dry matter) }}\end{array}$ \\
\hline $\mathrm{Al}$ & 9113.8 & 11.8 \\
\hline $\mathrm{Ca}$ & 31271.1 & 518.5 \\
\hline $\mathrm{Fe}$ & 1539.3 & 11.7 \\
\hline K & 7152.7 & 231.8 \\
\hline $\mathrm{Mg}$ & 882.5 & 58.1 \\
\hline $\mathrm{Na}$ & 4386.0 & 50.9 \\
\hline $\mathrm{P}$ & 36680.8 & 8.2 \\
\hline S & 4871.9 & 90.22 \\
\hline $\mathrm{Si}$ & 61730.3 & 157.3 \\
\hline As & 3.14 & - \\
\hline $\mathrm{Ba}$ & 103.46 & 21.08 \\
\hline $\mathrm{Cd}$ & 1.57 & 0.08 \\
\hline Co & 1.57 & 0.08 \\
\hline $\mathrm{Cr}$ & 12.54 & 0.16 \\
\hline $\mathrm{Cu}$ & 31.35 & 0.73 \\
\hline $\mathrm{Hg}$ & - & 0.08 \\
\hline $\mathrm{Mn}$ & 114.43 & 62.52 \\
\hline Mo & 4.70 & - \\
\hline $\mathrm{Ni}$ & 12.54 & 0.32 \\
\hline $\mathrm{Pb}$ & 23.51 & 0.89 \\
\hline $\mathrm{Sb}$ & 6.27 & 0.24 \\
\hline $\mathrm{Se}$ & 10.97 & 0.32 \\
\hline $\mathrm{Ti}$ & 28.22 & 1.21 \\
\hline $\mathrm{V}$ & 7.84 & - \\
\hline $\mathrm{Zn}$ & 194.38 & 8.00 \\
\hline
\end{tabular}

challenges to its pyrolysis due to the high potential of secondary environmental pollution. During thermal treatment significant amounts of feedstock-bound nitrogen, sulphur and chlorine are volatilised in the form of $\mathrm{NH}_{3}, \mathrm{HCN}, \mathrm{H}_{2} \mathrm{~S}$ and $\mathrm{HCl}[34,42]$ all of which are toxic and/or pollutants. When the pyrolysis gas is combusted these compounds are converted to their respective oxides (i.e. $\mathrm{NOx}, \mathrm{N}_{2} \mathrm{O}$ or $\mathrm{SO}_{\mathrm{x}}$ ) which are contributors to acid rain, greenhouse gas emissions or ozone layer depletion. Moreover $\mathrm{H}_{2} \mathrm{~S}$ is also corrosive. These compounds need to be removed from the gas in order to avoid corrosion and fouling in the engine.

The most common applications of pyrolysis chars are as a soil amendment [52]. As the BS has a relatively high ash content of about $30 \mathrm{wt} \%$, there will be a significant amount of the pyrolysis char generated, and given it's relatively low carbon content (Table 1) the resulting char will not meet the initial criteria in order to qualify as a biochar for soil applications according to European Biochar Certificate [53]. To overcome these limitations and increase the carbon content in the char the dried BS was mixed with spruce wood chips in a 50/50 ratio by weight. The properties of the wood and the mixture are also presented in Table 1. In spruce wood, the volatile matter content of $84 \mathrm{wt} \%$ was higher than in BS while the ash content was significantly lower at $0.49 \mathrm{wt} \%$. Also the sulphur, nitrogen and chlorine content were very low. The overall moisture content of the mixture was $11 \mathrm{wt} \%$ while the ash content in the mixture (14.7 wt\%) is half of that in the BS. Also the contents of $\mathrm{N}, \mathrm{S}$ and $\mathrm{Cl}$ were reduced, which will lead to a less contaminated pyrolysis gas.

\section{Pyrolysis Gas Composition}

The volumetric concentration of the gas components over the run time of a typical experiment, measured on-line at gas sampling point 3 (before the engine), is shown in Figs. 4 and 5 . It can be seen from the figures that the gas composition profiles for the major gas components in Fig. 5 had effectively stabilized after $15 \mathrm{~min}$. In order to ensure steady state

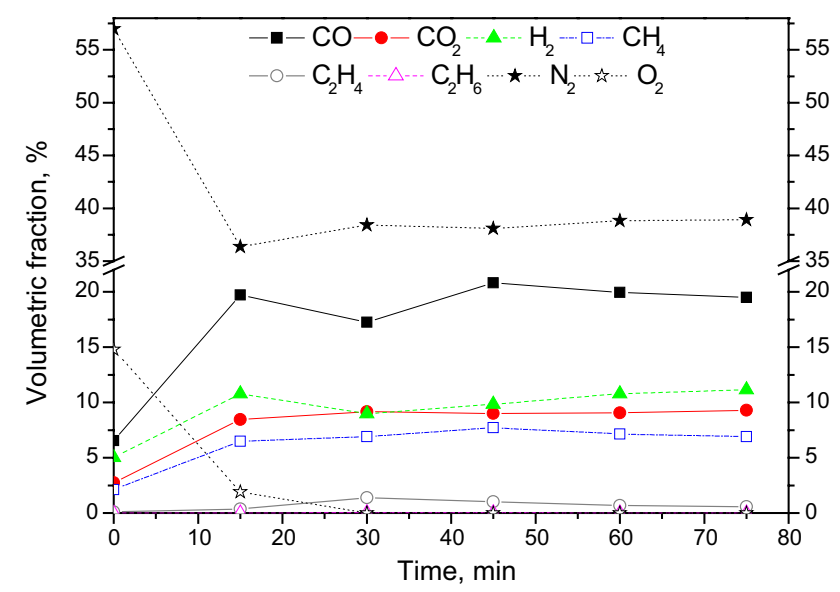

Fig. 4 Content of major gas components in pyrolysis gas after conditioning for Test 1

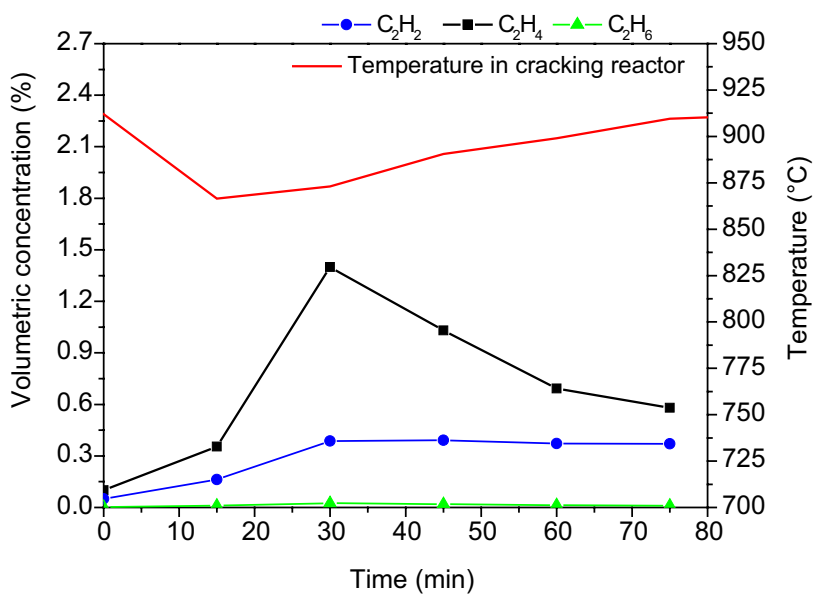

Fig. 5 Content of minor gas components in pyrolysis gas after conditioning for Test 1 
had been reached, an additional $15 \mathrm{~min}$ were allowed before sampling the product gas for tars and $\mathrm{NH}_{3}$. The concentration of $\mathrm{C}_{2} \mathrm{H}_{4}$ however stabilised only around $60 \mathrm{~min}$ after the feeding commenced. This could be related to temperature in the cracking reactor, which was controlled by adjusting the flow of air during the first $30 \mathrm{~min}$ of the test (for Test 1 it was increased from 0.420 to $0.620 \mathrm{Nm}^{3} / \mathrm{min}$ ) but another 30 min were required before the cracker temperature and $\mathrm{C}_{2} \mathrm{H}_{4}$ concentration approached stabilisation. The $\mathrm{C}_{2} \mathrm{H}_{4}$ is known to be an indicator of tar conversion/cracking [54-56].

The results from the pilot scale tests were evaluated and discussed as two separate cases, (1) when the pyrolysis gas is used without cleaning in a gas boiler and (2) when the

Table 4 Composition of pyrolysis gas collected before the tar cracker on $\mathrm{N}_{2}$ free basis (gas sampling port 1)

\begin{tabular}{llcl}
\hline Gases $($ vol\%) & Test 2 & Test 3 & Test 4 \\
\hline $\mathrm{H}_{2}$ & 6.5 & $11.9 \pm 0.3$ & $11.6 \pm 0.04$ \\
$\mathrm{CO}$ & 22.7 & $41.8 \pm 0.6$ & $32.0 \pm 0.4$ \\
$\mathrm{CO}_{2}$ & 12.6 & $20.4 \pm 0.2$ & $22.9 \pm 0.4$ \\
$\mathrm{CH}_{4}$ & 23.6 & $15.9 \pm 0.2$ & $15.1 \pm 0.5$ \\
$\mathrm{C}_{2} \mathrm{H}_{2}$ & 0.1 & $0.2 \pm 0.01$ & $0.2 \pm 0.00$ \\
$\mathrm{C}_{2} \mathrm{H}_{4}$ & 2.9 & $4.9 \pm 0.1$ & $4.5 \pm 0.1$ \\
$\mathrm{C}_{2} \mathrm{H}_{6}$ & 1.1 & $1.3 \pm 0.03$ & $1.6 \pm 0.0$ \\
$\mathrm{H}_{2} \mathrm{~S}(\mathrm{ppm})$ & 1220 & $1352 \pm 111$ & $1020 \pm 0.6$ \\
$\mathrm{NH}_{3}\left(\mathrm{~g} / \mathrm{m}^{3}\right)$ & 4.51 & $3.41 \pm 0.7$ & $7.27 \pm 0.4$ \\
$\mathrm{LHV}\left(\mathrm{MJ} / \mathrm{m}^{3}\right)$ & 12.2 & $16.1 \pm 0.1$ & $15.0 \pm 0.1$ \\
Total tar $\left(\mathrm{g} / \mathrm{Nm}^{3}{ }_{\text {dry gas }}\right.$ & 11.5 & $11.1 \pm 0.4$ & $13.9 \pm 0.2$ \\
Water content $\left(\mathrm{g} / \mathrm{Nm}^{3}{ }_{\text {dry gas }}\right)$ & - & $1151 \pm 207$ & $1618 \pm 126$ \\
Gas yield $\left(\mathrm{m}^{3} / \mathrm{h}\right)$ & $32.1 \pm 3.2$ & $36.9 \pm 0.7$ & $35.9 \pm 7.2$ \\
Gas yield $\left(\mathrm{m}^{3} / \mathrm{kg}_{\text {dry feed }}\right)$ & $0.39 \pm 0.04$ & $0.53 \pm 0.01$ & $0.47 \pm 0.09$ \\
\hline
\end{tabular}

pyrolysis gas is conditioned/cleaned to meet the specification of a gas engine.

In order to measure the pyrolysis gas composition without additional high temperature conditioning (tar cracking) samples of gas were collected in Tedlar bags from a pipe duct between the pyrolysis reactor and the tar cracking reactor, at gas sampling point 1 (see Fig. 1) and then analysed by micro GC. The resulting gas composition on an $\mathrm{N}_{2}$ free basis for Tests 2, 3 and 4 is presented in Table 4 . The calorific value of the untreated pyrolysis gas was relatively high at between 12 and $16 \mathrm{MJ} / \mathrm{m}^{3}$. The gas contained mainly $\mathrm{CO}$ (23-40 vol\%), $\mathrm{CH}_{4}(14-24 \mathrm{vol} \%), \mathrm{H}_{2}(6.5-12 \mathrm{vol} \%)$ and $\mathrm{CO}_{2}$ (13-20 vol\%). A total tar content of between 11.1 and $13.9 \mathrm{~g} / \mathrm{Nm}^{3}$ of $\mathrm{N}_{2}$ free gas was observed. The yield of pyrolysis gas was of 398,530 and $476 \mathrm{~m}^{3} /$ tonne of dry feedstock for Test 2, 3 and 4, respectively. Lepez et al. [57] reported higher calorific value of pyrolysis gas, $19.3 \mathrm{MJ} / \mathrm{m}^{3}$, obtained from pilot scale pyrolysis of sewage sludge at $800{ }^{\circ} \mathrm{C}$ in an integrated system of a contact drier and pyrolyser of Spirajoule technology. A much higher content of $\mathrm{H}_{2}$ of $21.4 \mathrm{vol} \%$ and $\mathrm{CH}_{4}$ of $39.1 \mathrm{vol} \%$ was observed in [57] compared to pyrolysis gas derived from BS and wood mixture.

During all the pilot scale tests, the conditioned pyrolysis gas was sampled inline every 10-15 min and analysed by micro GC. The average gas composition for steady state operation is presented in Table 5. The calorific value of the conditioned pyrolysis gas (from 6.9 to $7.7 \mathrm{MJ} / \mathrm{m}^{3}$ ) was lower than that of the raw gas. Since air was injected into the cracking reactor (see Table 2), the final gas was diluted with $\mathrm{N}_{2}$, which accounted for from 38 to $44 \mathrm{vol} \%$. Most of the tar compounds were cracked in the presence of $\mathrm{O}_{2}$ into $\mathrm{CO}$ and $\mathrm{H}_{2}$ while $\mathrm{CH}_{4}, \mathrm{C}_{2} \mathrm{H}_{4}$ and $\mathrm{C}_{2} \mathrm{H}_{6}$ were oxidised. The total tar content was reduced to $2.4,3.4$ and $7.7 \mathrm{~g} / \mathrm{Nm}_{\text {dry gas }}^{3}$ for Tests $2-4$ respectively. The change in the composition of
Table 5 Average composition of the pyrolysis gas at steady state operation after conditioning (gas sampling port 3)

\begin{tabular}{lllll}
\hline Gases (vol\%) & Test 1 & Test 2 & Test 3 & Test 4 \\
\hline $\mathrm{H}_{2}$ & $10.2 \pm 0.8$ & $11.4 \pm 0.9$ & $12.0 \pm 0.8$ & $6.1 \pm 0.3$ \\
$\mathrm{CO}$ & $19.4 \pm 1.3$ & $22.5 \pm 1.1$ & $21.9 \pm 0.5$ & $22.7 \pm 0.5$ \\
$\mathrm{CO}_{2}$ & $9.1 \pm 0.1$ & $11.2 \pm 0.3$ & $11.8 \pm 0.4$ & $11.0 \pm 0.3$ \\
$\mathrm{CH}_{4}$ & $7.2 \pm 0.3$ & $8.0 \pm 1.1$ & $6.6 \pm 0.8$ & $6.2 \pm 0.5$ \\
$\mathrm{C}_{2} \mathrm{H}_{2}$ & $0.4 \pm 0.01$ & $0.4 \pm 0.1$ & $0.3 \pm 0.1$ & $0.3 \pm 0.04$ \\
$\mathrm{C}_{2} \mathrm{H}_{4}$ & $0.9 \pm 0.3$ & $0.8 \pm 0.4$ & $0.6 \pm 0.3$ & $1.9 \pm 0.2$ \\
$\mathrm{C}_{2} \mathrm{H}_{6}$ & $0.02 \pm 0.01$ & $0.03 \pm 0.1$ & $0.01 \pm 0.01$ & $0.06 \pm 0.02$ \\
$\mathrm{~N}_{2}$ & $38.6 \pm 0.3$ & $41.9 \pm 9.4$ & $44.4 \pm 1.2$ & $44.1 \pm 0.7$ \\
$\mathrm{H}_{2} \mathrm{~S}(\mathrm{ppm})$ & $17.1 \pm 0.6$ & $17.8 \pm 8.5$ & - & $68.2 \pm 29$ \\
$\mathrm{NH}_{3}\left(\mathrm{~g} / \mathrm{m}^{3}\right)$ & - & $0.17 \pm 0.02$ & $0.12 \pm 0.06$ & $0.16 \pm 0.03$ \\
$\mathrm{LHV}\left(\mathrm{MJ} / \mathrm{m}^{3}\right)$ & $6.9 \pm 0.2$ & $7.7 \pm 0.7$ & $7.0 \pm 0.5$ & $7.1 \pm 0.3$ \\
Total tar $\left(\mathrm{g} / \mathrm{Nm}^{3}{ }_{\text {dry gas }}\right)$ & - & $2.3 \pm 0.3$ & $3.4 \pm 0.7$ & $7.7 \pm 0.8$ \\
Water content $\left(\mathrm{g} / \mathrm{Nm}_{\text {dry gas }}^{3}\right)$ & - & - & $27 \pm 12.7$ & - \\
Gas yield $\left(\mathrm{m}^{3} / \mathrm{h}\right)$ & - & $65.7 \pm 3.2$ & $63.3 \pm 0.7$ & $65.9 \pm 7.2$ \\
Gas yield $\left(\mathrm{m}^{3} / \mathrm{kg}_{\text {dry feed }}\right)$ & - & $0.82 \pm 0.04$ & $0.91 \pm 0.01$ & $0.87 \pm 0.09$ \\
\hline
\end{tabular}


the pyrolysis gas caused by the presence of $\mathrm{O}_{2}$ at high temperature can be explained by comparing the concentrations on a $\mathrm{N}_{2}$ free basis of these previously mentioned compounds leaving the pyrolysis and cracking reactors.

The concentration of $\mathrm{H}_{2}$ increased from 6.6 to $11.6 \mathrm{vol} \%$ before the cracker to 20-22 vol\% after the cracker for Tests 2 and 3. Morf et al. [54] reported that $\mathrm{H}_{2}$ was a good indicator of reactions that convert primary tars into aromatics, especially polycyclic aromatic hydrocarbons. This trend was not observed for Test 4 for which the temperature in the cracker $\left(800{ }^{\circ} \mathrm{C}\right)$ was too low for the decomposition of some tars and the $\mathrm{H}_{2}$ content remained at $11 \mathrm{vol} \%$. The concentration of CO increased from $23 \mathrm{vol} \%$ before to $40 \mathrm{vol} \%$ after the cracker for Test 2 and from 32 to 43 vol\% for Test 4 . On the other hand, the concentration of $\mathrm{CO}$ did not change and remained at $41 \mathrm{vol} \%\left(\mathrm{~N}_{2}\right.$ free basis) for Test 3 for which the temperature in the cracker was $900{ }^{\circ} \mathrm{C}$ but the flowrate of air was at its lowest at $26.4 \mathrm{Nm}^{3} / \mathrm{h}$. Another indicator of tar cracking is the concentration of $\mathrm{C}_{2} \mathrm{H}_{2}$ [56], which increased from 0.1 to $0.8 \mathrm{vol} \%$ (Test 2), 0.2 to 0.6 vol\% (Test 3) and from 0.2 to $0.5 \mathrm{vol} \%$ (Test 4 ) in the cracking reactor. The concentration of methane decreased from 23.6 before to $14.1 \mathrm{vol} \%$ after the cracker for Test 2 , while only a slight decreases in $\mathrm{CH}_{4}$ concentration from 15.9 to $12.1 \mathrm{vol} \%$ and 13.8 to 11.9 vol\% was observed for Tests 3 and 4 , respectively. In addition, the concentration of ethylene fell from 2.9 to $1.5 \mathrm{vol} \%$ (Test 2), 4.9 to $1.1 \mathrm{vol} \%$ (Test 3) and from 4.1 to $3.6 \mathrm{vol} \%$ (Test 4). The smallest reduction of $13 \%$ in $\mathrm{C}_{2} \mathrm{H}_{4}$ concentration, observed for Test 4 , was due to the lowest cracking temperature. The content of $\mathrm{C}_{2} \mathrm{H}_{6}$ was reduced in the cracker from 1.1 to 0.06 vol\% (Test 2), 1.3 to $0.02 \mathrm{vol} \%$ (Test 3 ) and from 1.5 to 0.11 vol\% (Test 4). The $\mathrm{O}_{2}$ from the injected air also oxidised the permanent gases such as $\mathrm{CH}_{4}$, $\mathrm{C}_{2} \mathrm{H}_{4}$ and $\mathrm{C}_{2} \mathrm{H}_{6}$ to form carbon dioxide, whose concentration on an $\mathrm{N}_{2}$ free basis increased from 12.6 to $19.9 \mathrm{vol} \%$ (Test 2), 20.4 to $21.6 \mathrm{vol} \%$ (Test 3) and from 20.9 to $21.1 \mathrm{vol} \%$ (Test 4).

Yields of conditioned pyrolysis gas of $820-910 \mathrm{~m}^{3} /$ tonne of dry feedstock were observed.

\section{Impurities in the Pyrolysis Gas: Tar Content and Composition}

The tar content and composition was measured in duplicate at the three sampling ports along the pilot scale facility and the results are presented in Table 6. The total tar yield was reduced significantly between sampling ports 1 and 2, from 11 to $13 \mathrm{~g} / \mathrm{Nm}^{3}$ of dry $\mathrm{N}_{2}$ free gas at port 1 to $2.3-3.5 \mathrm{~g} /$ $\mathrm{Nm}_{\text {dry gas }}^{3}$ at port 2, located after the thermal cracking reactor. Further conditioning of the pyrolysis gas did not have much influence on the tar content measured at port 3, except for Test 4.
Table 6 Yields of total GC detectable measured by SPA sampling

\begin{tabular}{clll}
\hline & \multicolumn{2}{l}{ Total GC detectable tar } & \\
\cline { 2 - 4 } & Port 1 & Port 2 & \\
& $\mathrm{g}_{\text {total tar }} /$ & $\mathrm{g}_{\text {total tar }} / \mathrm{Nm}^{3}{ }_{\text {dry gas }}$ & \\
& $\mathrm{Nm}_{\text {dry N2 free gas }}$ & & \\
\hline Test 2 & & & 2.47 \\
$\mathrm{a}$ & 11.10 & 3.14 & 2.08 \\
$\mathrm{~b}$ & 11.83 & 1.49 & \\
Test 3 & & & 3.93 \\
$\mathrm{a}$ & 10.84 & 2.79 & 2.96 \\
$\mathrm{~b}$ & 11.41 & 2.98 & \\
Test 4 & & & 7.28 \\
$\mathrm{a}$ & 13.76 & 3.40 & 7.11 \\
$\mathrm{~b}$ & 14.01 & 3.53 & \\
\hline
\end{tabular}

Table 7 shows the yields of all identified tar compounds measured during Test 3 , denominated according to the IUPAC nomenclature and listed in the order in which they eluted. At the 1st sampling point, which corresponds to tars released/formed in the pyrolysis reactor, nine $\mathrm{N}$-containing tar species were identified (in Table 7 denoted with*). Depending on the test, the yields of nitrogen-containing tar compounds account for $8.0-16.8 \%$ of total tar. 2-Butenenitrile, pyridine and $1 H$-pyrrole are found to be the most abundant N-containing tar compounds. Anzar et al. [58] reported that $16 \%$ of the total $\mathrm{N}$ input was released as $\mathrm{N}$-containing tar compounds during gasification of sewage sludge at $725{ }^{\circ} \mathrm{C}$. N-containing compounds were also reported to be present in bio-oil obtained from sewage sludge pyrolysis at $500{ }^{\circ} \mathrm{C}$ [59]. These compounds are precursors for $\mathrm{N}$-containing pyrolysis tar whose formation is promoted by increasing pyrolysis temperature and extending the residence time. In the current study, at a pyrolysis temperature of around $700{ }^{\circ} \mathrm{C}$, the tars undergo secondary reforming reactions making their structure less heterocyclic and more aromatic. $\mathrm{N}$-containing tar is considered problematic due to the carcinogenic and mutagenic character of their aromatic analogues [59]. N-containing tar is water soluble, adding organic load to the aqueous liquor which will require treatment. Other identified constituents are well-known pyrolysis tar including aromatic hydrocarbons among which the most abundant ones were: benzene, toluene, styrene, indene, and naphthalene Along with that $\mathrm{O}$-containing aromatic compounds were represented by phenol, cresols, and phenol 2,5-dimethyl.

At a temperature of about $900{ }^{\circ} \mathrm{C}$ and in the presence of oxygen, all of the nitrogen-containing tars were cracked, and consequently were not detected at sampling port 2 located after the cracking reactor (Table 7). The tar composition sampled at ports 2 and 3 was found to be similar, consisting of aromatic hydrocarbons only. The yields of total tar 
Table 7 Identified tar compounds with their chromatographic retention time for Test 3

\begin{tabular}{|c|c|c|c|c|c|c|c|c|}
\hline & Tar compounds & Retention time & $\begin{array}{l}\mathrm{g}_{\text {total tar }} \\
\mathrm{Nm}^{3} \mathrm{dr}\end{array}$ & ree gas & $\mathrm{g}_{\text {total tar }}$ & $1^{3}$ dry gas & & \\
\hline & & & Port 1 & & Port 2 & & Port 3 & \\
\hline & & & a & $\mathrm{b}$ & a & $\mathrm{b}$ & a & $\mathrm{b}$ \\
\hline 1 & 2-Methylpropanenitrile (isobutyronitrile)* & 2.175 & 0.105 & 0.090 & - & - & - & - \\
\hline 2 & 5-Methylcyclopenta-1,3-diene & 2.268 & 0.256 & 0.212 & - & - & - & - \\
\hline 3 & 2-Butenenitrile* & 2.350 & 0.188 & 0.157 & - & - & - & - \\
\hline 4 & Benzene & 2.928 & 0.568 & 0.637 & 1.831 & 1.978 & 3.616 & 2.757 \\
\hline 5 & Pyrazine* & 4.332 & 0.025 & 0.018 & - & - & - & - \\
\hline 6 & Pyridine* & 4.707 & 0.259 & 0.263 & - & - & - & - \\
\hline 7 & $1 H$-Pyrrole* & 5.280 & 0.286 & 0.280 & - & - & - & - \\
\hline 8 & Toluene & 5.340 & 0.863 & 0.816 & 0.026 & 0.025 & 0.061 & 0.043 \\
\hline 9 & 2-Methylpyridine* & 7.320 & 0.085 & 0.079 & - & - & - & - \\
\hline 10 & 4-Methylpyrimidine* & 7.507 & 0.049 & 0.055 & - & - & - & - \\
\hline 11 & 4-Methylpentanenitrile* & 8.260 & 0.018 & 0.013 & - & - & - & - \\
\hline 12 & Ethylbenzene & 8.758 & 0.129 & 0.108 & 0.001 & 0.001 & 0.001 & 0.002 \\
\hline 13 & 1,2/1,3/1,4-Dimethylbenzene (o/m/p xylene) & 9.067 & 0.215 & 0.223 & 0.004 & 0.003 & 0.004 & 0.004 \\
\hline 14 & Ethynylbenzene & 9.585 & - & - & 0.008 & 0.005 & 0.013 & 0.009 \\
\hline 15 & Ethenylbenzene (styrene) & 9.883 & 0.662 & 0.668 & 0.014 & 0.009 & 0.033 & 0.023 \\
\hline 16 & 2-Methyl-2-cyclopenten-1-one & 10.613 & 0.063 & 0.054 & - & - & - & - \\
\hline 17 & 1-Ethyl-3-methylbenzene (3-ethyltoluene) & 12.445 & 0.051 & 0.049 & - & - & - & - \\
\hline 18 & Benzenecarbonitrile (Benzonitrile)* & 13.333 & 0.078 & 0.087 & - & - & - & - \\
\hline 19 & 1-Ethyl-2-methylbenzene (2-ethyltoluene) & 13.597 & 0.345 & 0.369 & - & - & - & - \\
\hline 20 & Benzenol (phenol) & 13.857 & 0.921 & 0.993 & - & - & - & - \\
\hline 21 & $1 H$-Indene & 15.182 & 0.398 & 0.496 & 0.006 & 0.009 & - & - \\
\hline 22 & 2/3/4-Methylphenol (o/m/p cresol) & 16.062 & 0.446 & 0.474 & 0.004 & 0.003 & - & - \\
\hline 23 & 2/3/4-Methylphenol (o/m/p cresol) & 16.795 & 0.725 & 0.785 & - & - & - & - \\
\hline 24 & 1,2-Dihydronaphthalene & 18.650 & 0.148 & 0.163 & - & - & - & - \\
\hline 25 & 2,5-Dimethylphenol & 18.885 & 0.232 & 0.251 & - & - & - & - \\
\hline 26 & Naphthalene & 19.500 & 0.588 & 0.779 & 0.363 & 0.374 & 0.020 & 0.009 \\
\hline 27 & 2-Methylnaphthalene & 22.613 & 0.206 & 0.247 & - & - & - & - \\
\hline 28 & 1-Methylnaphthalene & 23.052 & 0.123 & 0.126 & - & - & - & - \\
\hline 29 & 1,1'-Biphenyl & 24.895 & 0.039 & 0.046 & - & - & - & - \\
\hline 30 & 2-Ethenylnaphthalene & 26.138 & 0.056 & 0.070 & - & - & - & - \\
\hline 31 & Acenaphthylene & 26.583 & 0.136 & 0.163 & 0.118 & 0.113 & - & - \\
\hline 32 & $9 H$-Fluorene & 29.778 & 0.051 & 0.055 & - & - & - & - \\
\hline 33 & Phenanthrene & 34.070 & 0.106 & 0.112 & 0.073 & 0.064 & - & - \\
\hline 34 & Anthracene & 34.285 & 0.037 & 0.045 & - & - & 0.011 & 0.011 \\
\hline 35 & 4H-Cyclopenta[def]phenanthrene & 36.955 & - & - & 0.008 & 0.007 & - & - \\
\hline 36 & Fluoranthene & 39.550 & 0.024 & 0.028 & 0.047 & 0.047 & 0.012 & 0.002 \\
\hline 37 & Pyrene & 40.468 & 0.018 & 0.021 & 0.008 & 0.003 & - & - \\
\hline 38 & Cyclopenta[cd]pyrene & 46.133 & 0.033 & 0.036 & 0.069 & 0.080 & 0.020 & 0.010 \\
\hline 39 & Tetraphene (benz[a]anthracene) & 46.215 & - & - & 0.022 & 0.024 & 0.006 & 0.006 \\
\hline 40 & Benzo[k]fluoranthene & 52.013 & 0.013 & 0.012 & - & - & - & - \\
\hline 41 & Benz[e]acephenanthrylene & 52.238 & 0.013 & 0.012 & - & - & - & - \\
\hline 42 & Indeno[1,2,3-cd]pyrene & 57.178 & 0.004 & 0.004 & 0.005 & 0.010 & - & - \\
\hline
\end{tabular}

Yields of individual tar compounds measured by duplicate SPA sampling 
sampled at port 3 were expected to be lower compared to those at port 2. It had been anticipated that the water scrubber and activated carbon filter mounted between ports 2 and 3 should have removed a portion of the tar from the pyrolysis gas, however, this was not observed in the present study. Table 6 indicates similar or even higher total tar contents for both ports. This may also be due to the difference in sampling temperature as temperature affects the gas density with colder gas having higher density which gives arise to higher total tar yields. The temperature at port 2 was around $500{ }^{\circ} \mathrm{C}$, while the port 3 was kept at ambient temperature. Only a single sulphur-containing compound (benzothiophene) was identified and only in Test 4.

The calculations indicated that total tar comprises $0.5 \mathrm{wt} \%$ of the initial weight of the BS and wood mixture. Dominguez et al. [60] reported a yield of total tar lower than $1 \mathrm{wt} \%$ of the sewage sludge feedstock when sampling tar using a wet condensation method.

Tar content could be viewed from two different perspectives, which depend on the final use of the pyrolysis gas. When the hot raw gas is combusted directly such as in boilers or industrial kilns, tars are a source of energy not accounted for in the calorific value of the dry pyrolysis gas. There is little chance of tar condensation and thus there is no need for tar removal and usually no tar limits are specified. The N-containing tars however will release HCN and $\mathrm{NH}_{3}$ mainly through secondary thermal cracking and during combustion NOx and $\mathrm{N}_{2} \mathrm{O}$ will be released. Therefore, deNOx technology would be required.

However, for use in an internal combustion gas engine tar has to be removed to levels specified by manufacturers. Internal combustion engines require cooled gas, where there is a probability of tar condensation inside the engine or in the fuel-injection systems. In general, tar concentrations in the gas should be well below $100 \mathrm{mg} / \mathrm{Nm}^{3}$ [61] but each manufacturer provides their own specifications. For the Dresser-Rand Group [62] gas engine used in this investigation, gasification or pyrolysis tar limits are specified for tar groups differentiated according to the number of aromatic rings. Single aromatic ring $\operatorname{tar}<1.5 \mathrm{~g} / \mathrm{MJ}, 2$ aromatic rings $<0.2 \mathrm{~g} / \mathrm{MJ}, 3$ aromatic rings $<0.003 \mathrm{~g} / \mathrm{MJ}$, and no tar compounds with four aromatic rings or more are allowed to enter the gas engine. The manufacturer also proposes the CEN/BT/TF 143 standard technical specification, also known as the tar protocol rather than the SPA method, as a methodology for determination of the tar content in the gas. As an example, the average calorific value of raw and dry pyrolysis gas (excluding the tar fraction) derived from BS and wood chips feedstock from Test 3 at sampling port 3 was 6.9 MJ $/ \mathrm{Nm}^{3}$. Thus, the upper tar limits for a Dresser-Rand gas engine for BS and wood mixture would have been 10.4, 1.4 , and $0.02 \mathrm{~g} / \mathrm{Nm}^{3}$ referring to 1,2 , and 3 aromatic rings compounds, respectively. Given that the tar limits are based on the number of aromatic rings, it suggests that the tar composition is as important as the total tar. Parameters such as tar dew point or selection of a suitable tar removal method will depend on tar composition rather than on total tar.

The raw pyrolysis gas was conditioned in order to remove problematic tar compounds that could cause fouling of the process installation. Table 8 shows the tar compounds grouped and classified on the basis of number of aromatic rings as measured from sampling ports 1, 2 and 3 for Test 3 . The 1, 2 and 3 aromatic ring tars were below the maximum tar limits specified by Dresser-Rand. However, despite the thermal cracking and subsequent water scrubbing together with activated carbon filtration the four aromatic ring tar group compounds (anthracene, $4 H$-cyclopenta[def]phenanthrene, fluoranthen, pyrene, cyclopenta[cd]pyrene, tetraphene, benz[e]acephenanthrylene, indeno[1,2,3-cd]pyrene) still remain in the pyrolysis gas. These are not allowed by the specification. Note that the tar group denominated as unknown equals the quantities of identified species. An efficient tar mitigation system is required if pyrolysis gas is to be used in internal combustion gas engines.

\section{Impurities in the Pyrolysis Gas: $\mathrm{NH}_{3}$ and $\mathrm{H}_{2} \mathrm{~S}$}

During pyrolysis Test 2, 3 and 4 an attempt was made to quantify the content of $\mathrm{NH}_{3}$ in the pyrolysis gas. The measured ammonia concentrations before gas conditioning varied from 3.4 to $7.2 \mathrm{~g} / \mathrm{Nm}^{3}$ (see Table 4) which accounts for only about $6 \%$ of the total nitrogen input into the system for the BS and wood mixture (Table 9). This value is lower than reported in the literature, e.g. Wei et al. [63] observed that $16 \%$ of fuel- $\mathrm{N}$ converted into $\mathrm{NH}_{3}$ during pyrolysis of sewage sludge while Aznar at al [58]. reported that over $20 \%$ of fuel-N turned into $\mathrm{NH}_{3}$ during gasification of sewage sludge. The fact that only a fraction of $\mathrm{NH}_{3}$ was measured in this study could be an indication that the insulation of sampling lines used during gas sampling was insufficient to prevent condensation. On the other hand, it has been reported that during gasification of $\mathrm{N}$-containing sewage sludge, up to $44 \%$ of the nitrogen was released as $\mathrm{N}_{2}$ [58] as a result of catalytic effect of the mineral matter. In the present study it was difficult to distinguish between the $\mathrm{N}_{2}$ entering the system with air in the interstices between the feedstock particles

Table 8 The yields of tar groups classified according to the number of aromatic rings in the compound for Test 3

\begin{tabular}{llllll}
\hline & \multicolumn{4}{l}{$\operatorname{Sum}\left(\mathrm{g}_{\mathrm{tar}} / \mathrm{Nm}_{\text {dry gas }}^{3}\right)$} \\
\cline { 2 - 6 } & $\Sigma 1$ ring & $\Sigma 2$ ring & $\Sigma$ 3 ring & $\Sigma$ 4+ ring & Unknown \\
\hline Port 1 & 4.04 & 1.16 & 0.23 & 0.07 & 1.91 \\
Port 2 & 1.96 & 0.37 & 0.18 & 0.19 & 0.18 \\
Port 3 & 3.28 & 0.01 & 0.01 & 0.03 & 0.11 \\
\hline
\end{tabular}


Table 9 Partitioning of nitrogen between char and $\mathrm{NH}_{3}$ excluding $\mathrm{N}$-containing tar compounds for pyrolysis of BS with wood

\begin{tabular}{llllcll}
\hline & $\begin{array}{l}\mathrm{N} \text { content, } \\
\text { wt\% dry basis }\end{array}$ & $\begin{array}{l}\text { \% of } \mathrm{N} \\
\text { retained in } \\
\text { char }\end{array}$ & $\begin{array}{l}\text { \% of } \mathrm{N} \text { in gas } \\
\text { as } \mathrm{NH}_{3} \text { Port 1 }\end{array}$ & $\begin{array}{l}\text { \% of } \mathrm{N} \text { in gas } \\
\text { as } \mathrm{NH}_{3} \text { Port 2 }\end{array}$ & $\begin{array}{l}\text { \% of } \mathrm{N} \text { in gas } \\
\text { as } \mathrm{NH}_{3} \text { Port 3 }\end{array}$ & $\begin{array}{l}\text { \% of N missing } \\
\text { (not measured) }\end{array}$ \\
\hline Test 2 & $3.04(100 \%)$ & 27.68 & 4.86 & 5.41 & 0.37 & $\sim 70$ \\
Test 3 & $3.04(100 \%)$ & 19.26 & 5.16 & 10.94 & 0.31 & $\sim 70$ \\
Test 4 & $3.04(100 \%)$ & - & 9.36 & 2.51 & 0.39 & - \\
\hline
\end{tabular}

and $\mathrm{N}_{2}$ potentially released from the $\mathrm{BS}$ and wood mixture. The concentration of HNC was not measured in the current study however it was reported in the literature that the fraction of the $\mathrm{N}$ released in the form of $\mathrm{HNC}$ can be similar to $\mathrm{NH}_{3}$ [63] or smaller [42, 58] depending mainly on heating rate used. When we consider all the limitation of the current system set-up, a significant amount of the nitrogen input with the feedstock was not accounted for. Around $0.5 \%$ of $\mathrm{N}$ was released as nitrogen containing tars.

Although, over $90 \%$ of the ammonia was removed from the gas in the water scrubber the $\mathrm{NH}_{3}$ remaining (17.4-22.5 mg/MJ) exceeds the recommended limit of $1.5 \mathrm{mg} / \mathrm{MJ}$ for Dresser-Rand internal combustion engine. By mixing BS with wood, it was possible to dilute/reduce $\mathrm{NH}_{3}$ content in the pyrolysis gas but still the requirements for gas engine application with the selected engine were not met. The pilot scale pyrolysis facility used in this case is typically used for testing materials which do not contain high amounts of nitrogen, therefore it is believed that it is possible to improve and optimise the scrubber cleaning section. If, this will not be possible the fraction of wood mixed with the BS needs to be increased in order to further dilute the concentration of $\mathrm{NH}_{3}$.

An initial sulphur content of $0.4 \%$ was detected in the BS and wood mixture, of which between 44 and $31 \%$ was retained in the char after pyrolysis (Table 10), consequently the balance (56 and 69\%) was released in a gaseous form or as a condensable or water soluble fraction. Only about $20 \%$ of the initial $\mathrm{S}$ input was detected in the gas as $\mathrm{H}_{2} \mathrm{~S}$ (before water scrubbing) suggesting that about $40 \%$ of $S$ input into the system was missing/not measured. The content of $\mathrm{H}_{2} \mathrm{~S}$ in the conditioned pyrolysis gas was much lower than in the raw gas 17-68 ppm versus 1020-1300 ppm, respectively, while the concentration of $S$ in the water leaving the scrubber increased from 5.6 to $15.2 \mathrm{ppm}$. Zhan et al. [34] reported about $50 \%$, retention of S in char for sewage sludge pyrolysis and the remaining $\mathrm{S}$ was more or less equally distributed between $\mathrm{N}$-gas and $\mathrm{N}$-tar products.

The equivalent concentration of $\mathrm{H}_{2} \mathrm{~S}$ in the conditioned pyrolysis gas varying from 3.8 to $14.6 \mathrm{mg} / \mathrm{MJ}$ is below the maximum permissible limit of $\mathrm{H}_{2} \mathrm{~S}$ equivalent which is set to $70 \mathrm{mg} / \mathrm{MJ}$ for Siemens (Dresser-Rand Group) gas engine.

\section{Mass Balance for Pyrolysis Products}

The consistency of the results was evaluated by performing a mass balance for the main elements based on the total flows of input streams, on a dry basis. The results for Test 3 are presented in Table 11. The input stream of BS and wood was differentiated into dry feedstock and moisture. The elemental flow rate of the BS and wood mixture was calculated according to the elemental and proximate composition shown in Table 1. The second input flow was the air for the cracking reactor. Two scenarios were evaluated for the output pyrolysis gas (1) $\mathrm{N}_{2}$ free gas without cleaning and (2) with cleaning/conditioning. The mass output flows were segregated into dry product gas, char and moisture measured in the pyrolysis gas, and tar. This last stream was the total GC detectable tar obtained using the SPA method as benzene.

The overall mass balance, for the first scenario showed $124 \%$ difference between input and output for the total mass flow. This discrepancy may originate mainly from inaccuracy of the measuring devices (flowmeters), since the yield of unconditioned pyrolysis gas was calculated by difference between the final volume of the gas and the volume of air injected into the cracking reactor. Moreover, there were always small amount of humid air entering the system with the feedstock (interstices between wood chips and dried BS particles) increasing the total moisture and nitrogen content in the gas. The best balance closure of $94 \%$ was observed

Table 10 Partitioning of sulphur between char and $\mathrm{H}_{2} \mathrm{~S}$ excluding S-containing tar compounds for pyrolysis of BS with wood

\begin{tabular}{lllllll}
\hline & S content, wt\% dry basis & $\begin{array}{l}\text { \% of S retained } \\
\text { in char }\end{array}$ & $\begin{array}{l}\text { \% of S in gas as } \\
\mathrm{H}_{2} \mathrm{~S} \text { Port 1 }\end{array}$ & $\begin{array}{l}\text { \% of S in gas as } \\
\mathrm{H}_{2} \mathrm{~S} \text { Port 2 }\end{array}$ & $\begin{array}{l}\text { \% of S in gas as } \\
\mathrm{H}_{2} \mathrm{~S} \text { Port 3 }\end{array}$ & $\begin{array}{l}\text { \% of S missing } \\
\text { (not measured) }\end{array}$ \\
\hline Test 2 & $0.40(100 \%)$ & 44.62 & 15.58 & - & 0.81 & $\sim 40$ \\
Test 3 & $0.40(100 \%)$ & 30.65 & 22.76 & 17.80 & - & $\sim 47$ \\
Test 4 & $0.40(100 \%)$ & - & 15.57 & 21.66 & 1.91 & - \\
\hline
\end{tabular}


Table 11 Mass balance for pyrolysis products for Test 3

\begin{tabular}{|c|c|c|c|c|c|c|c|}
\hline Test 3 & Mass flow $(\mathrm{kg} / \mathrm{h})$ & $\mathrm{C}\left(\mathrm{kg}_{\mathrm{db}} / \mathrm{h}\right)$ & $\mathrm{H}\left(\mathrm{kg}_{\mathrm{db}} / \mathrm{h}\right)$ & $\mathrm{N}\left(\mathrm{kg}_{\mathrm{db}} / \mathrm{h}\right)$ & $\mathrm{S}\left(\mathrm{kg}_{\mathrm{db}} / \mathrm{h}\right)$ & $\mathrm{Cl}\left(\mathrm{kg}_{\mathrm{db}} / \mathrm{h}\right)$ & $\mathrm{O}\left(\mathrm{kg}_{\mathrm{db}} / \mathrm{h}\right)$ \\
\hline \multicolumn{8}{|l|}{ Input streams } \\
\hline BS + wood (dry) & 69.63 & 29.91 & 4.24 & 2.12 & 0.28 & 0.08 & 22.78 \\
\hline Moisture with BS + wood & 8.58 & & 0.95 & & & & 7.63 \\
\hline Air for cracking reactor & 31.38 & & & 24.01 & & & 7.37 \\
\hline Total mass flow & 109.59 & 29.91 & 5.19 & 26.13 & 0.28 & 0.08 & 37.78 \\
\hline \multicolumn{8}{|c|}{ Output streams: pyrolysis gas without cleaning } \\
\hline Char & 19.57 & 11.13 & 0.36 & 0.46 & 0.10 & - & 0.45 \\
\hline Gas from pyrolysis (dry) & 38.94 & 16.78 & 1.78 & 0.11 & 0.06 & & 20.31 \\
\hline Moisture in the gas & 37.73 & & 4.72 & & & & 37.73 \\
\hline Tar (all as benzene) & 0.41 & 0.38 & 0.03 & 0.01 & & & \\
\hline Total mass flow & 96.95 & 28.29 & 6.89 & 0.58 & 0.17 & & 58.49 \\
\hline Out/in $(\%)$ & 124.00 & 94.65 & 132.75 & 27.36 & 57.14 & & 192.33 \\
\hline \multicolumn{8}{|c|}{ Output streams: pyrolysis gas after cleaning } \\
\hline Char & 19.57 & 11.13 & 0.36 & 0.46 & 0.10 & - & 0.45 \\
\hline Gas after conditioning (dry) & 66.32 & 13.24 & 1.42 & 32.74 & - & & 18.92 \\
\hline Moisture in the gas & 1.71 & & 0.19 & & & & 1.52 \\
\hline Tar (all as benzene) & 0.22 & 0.20 & 0.02 & & & & \\
\hline Total mass flow & 87.82 & 24.57 & 1.99 & 33.2 & 0.10 & & 20.89 \\
\hline Out/in (\%) & 80.13 & 82.14 & 38.34 & 127.10 & 35.71 & & 55.29 \\
\hline
\end{tabular}

for carbon. The $\mathrm{N}$ content measured in the output streams accounts for only $27 \%$ of the total nitrogen input. This could be due to the sampling procedures for $\mathrm{NH}_{3}$ and the fact that $\mathrm{HCN}$ was not measured. Similarly, in case of S content only $57 \%$ of the total sulphur input was measured in the output streams. The greatest discrepancies were observed in the $\mathrm{H}$ and $\mathrm{O}$ mass balances. There was more $\mathrm{H}(132 \%)$ and $\mathrm{O}$ (192\%) in the output streams which was probably due to the moisture present in the air entering with the feedstock as well as the accuracy of water content determination.

The overall mass balance, for the second scenario showed an $80 \%$ difference between input and output for the total mass flow. This discrepancy originates mainly from the facts that almost all the moisture was removed from the gas steam in the dehumidifier, while ammonia, water-soluble tars and other compounds were removed in the gas cleaning section. Inaccuracy of the measuring devices (flowmeters) could have also contributed to the observed difference. The best balance closures of $82 \%$ was observed for carbon, for which the missing mass was mainly due to losses with particulates in the filter and water-soluble organic compounds. The $\mathrm{N}$ content measured in the output stream was $27 \%$ higher than the total nitrogen input, due to air entering with the feedstock and inaccuracy of flowmeters. The S content measured in the output streams accounts only for $35 \%$ of the total sulphur input, since $\mathrm{H}_{2} \mathrm{~S}$ was removed from the gas in the scrubber. There was less $\mathrm{H}(38 \%)$ and $\mathrm{O}(55 \%)$ measured in the output streams than in the input, which was due to the removal of moisture from the final gas and the accuracy of water content determination.

\section{Energy Balance for Pyrolysis Products}

The information obtained from the pyrolysis Test 3 was used for the energy balance for the pyrolysis products (Table 12). The energy entering with the BS and wood mixture and the energy flows of the exit streams (gas, char and tar) were evaluated on the basis of the lower heating value of and the mass balance of the pyrolysis process for the two scenarios as presented in Table 11. The energy content in tar was calculated for benzene, the most abundant tar compound (Table 7).

The total energy entering the pyrolysis system with the BS and wood mixture (as fed with $11 \%$ moisture) was 1118.4 MJ/h. The overall energy balance closure for the first scenario (pyrolysis gas without cleaning) for all pyrolysis products was $89.4 \%$. The $10 \%$ discrepancy between the input and the output energy flows was partially carried over from the mass balance and was related to the inaccuracy of measuring devices and there was additional inaccuracy related to determination of the calorific value of the products. Most of the initial energy content of the feedstock was retained in the pyrolysis gas, 53\%. A substantial amount of the energy was preserved in the char, $34.5 \%$. The tar accounted for $1.5 \%$ with $\mathrm{NH}_{3}$ representing $0.35 \%$ of the initial energy content of the $\mathrm{BS}$ and wood mixture. 
Table 12 Energy balance for pyrolysis products for Test 3

\begin{tabular}{lrr}
\hline Test 3 & Energy flow $(\mathrm{MJ} / \mathrm{h})$ & $\%$ \\
\hline Input streams & & 100.00 \\
BS + wood & 1118.40 & \\
Output streams: pyrolysis gas without cleaning & & 34.47 \\
Char & 385.53 & 53.14 \\
Gas from pyrolysis (dry) & 594.32 & 1.51 \\
Tar (all as benzene) & 16.87 & 0.27 \\
$\mathrm{NH}_{3}$ & 2.99 & 89.39 \\
Total energy flow & 999.70 & \\
Output streams: pyrolysis gas after cleaning & & 34.47 \\
Char & 385.53 & 39.18 \\
Gas after conditioning (dry) & 438.20 & 0.81 \\
Tar (all as benzene) & 9.05 & 0.02 \\
$\mathrm{NH}_{3}$ & 0.18 & 74.48 \\
Total energy flow & 832.96 & \\
\hline
\end{tabular}

Table 13 Properties of pyrolysis char from pilot scale tests for BS and wood mixture

\begin{tabular}{lccl}
\hline Properties, wt\% dry basis & Test 1 & Test 2 & Test 3 \\
\hline Ash content & 36.06 & 40.63 & 35.90 \\
Volatile matter & 11.57 & 14.86 & - \\
Fixed carbon & 52.37 & 44.51 & - \\
LHV (MJ/kg) & 20.19 & 18.46 & 19.87 \\
C & 57.93 & 52.30 & 57.10 \\
H & 1.58 & 1.78 & 1.85 \\
N & 2.44 & 2.64 & 2.34 \\
S & 0.52 & 0.56 & 0.49 \\
Cl & 0.29 & 0.25 & 0.14 \\
O & 1.17 & 1.84 & 2.31 \\
\hline
\end{tabular}

The overall energy balance closure for the second scenario (pyrolysis gas after cleaning) for all pyrolysis products was $74.5 \%$. The $25 \%$ discrepancy between the input and the output energy flows was related to energy loses due to oxidation of the primary pyrolysis products $\mathrm{CH}_{4}$ and $\mathrm{C}_{2} \mathrm{H}_{4}, \mathrm{C}_{2} \mathrm{H}_{6}$, in the cracking reactor which could not be compensated by tar cracking. Again any discrepancy arose partially from the mass balance with some contribution from inaccuracy related to determination of calorific value of the products. The percent of the initial energy content of the feedstock retained in the pyrolysis gas was slightly higher than that retained in the char $39.2 \%$ versus $34.5 \%$. The tar retained only $0.8 \%$ while $\mathrm{NH}_{3}, 0.02 \%$ of the initial energy content of the $\mathrm{BS}$ and wood mixture.

\section{Properties of Pyrolysis Char}

The proximate and ultimate properties of chars from the pilot scale tests are presented in Table 13. The pyrolysis chars consisted mainly of fixed carbon of 44.5 and $52.5 \mathrm{wt} \%$ on a dry basis. The volatile matter contents of $11.6 \%$ and $14.8 \%$ indicated that the majority of the organic matter had been decomposed. The carbon content in the char was from 52 to $57 \mathrm{wt} \%$, which meets the criteria set by the European Biochar Certificate (EBC) [53]. Other properties specified in the EBC [53] should be measured in order to determine if the material could be qualified as biochar for agricultural use.

The mass balance calculations for Test 2 and Test 3 presented in Table 10 revealed that between 28 and $19 \%$ of the initial $\mathrm{N}$ was retained in the char, which is similar to results reported in literature [58]. Regarding S content, after pyrolysis between 44 and $31 \%$ was retained in the char (Table 10) which is lower than data reported by Zhan et al. [34] who found $50 \%$, retention of $S$ in the char for sewage sludge pyrolysis. For chlorine, between 64 and $70 \%$ was retained in the char, while the remainder was released in a gaseous form or as a condensable or water-soluble fraction.

The yield of pyrolysis char was from 250 to $320 \mathrm{~kg} /$ tonne of the BS and wood mixture fed into the pyrolyser. The bulk density of the char was $135 \mathrm{~kg} / \mathrm{m}^{3}$. Lepez et al. [57] reported similar yield of char of $29 \%$ for sewage sludge and $41 \%$ for sewage sludge mixed with lime for pilot scale pyrolysis at $800{ }^{\circ} \mathrm{C}$ in an integrated system of a contact drier and pyrolyser of Spirajoule technology.

Although, other properties of the char obtained which are relevant to soil application need to tested, and the final decision about its suitability will be made in the future, based on results available in the scientific literature we would like to elaborate about the benefits of biochar in agriculture. The biochar obtained is sterilised and is easy to transport long distances. Biochar increases soil water storage capacity, hydraulic conductivity, internal drainage, and aeration of the topsoil especially in medium and heavy soils $[64,65]$. 
Borchard et al. [66] have systematically analysed the effect of biochars made from various feedstock on soils and concluded that biochar produced from wood or lignocellulosic biomass reduced soil $\mathrm{N}_{2} \mathrm{O}$ emissions while emissions were unaffected after application of biochar made from biosolids. The $\mathrm{N}_{2} \mathrm{O}$ emissions were reduced regardless of soil texture. Moreover, biochars produced at temperatures of $>500{ }^{\circ} \mathrm{C}$ reduced $\mathrm{NO}_{3}{ }^{-}$leaching. The char produced at $700{ }^{\circ} \mathrm{C}$ from the mixture of $\mathrm{BS}$ and wood may have properties which will reduce $\mathrm{N}_{2} \mathrm{O}$ emissions and $\mathrm{NO}_{3}{ }^{-}$leaching while providing macro and micro nutrients such as $\mathrm{N}, \mathrm{P}, \mathrm{Mg}, \mathrm{K}, \mathrm{Ca}, \mathrm{S}, \mathrm{Fe}$, $\mathrm{Mn}, \mathrm{Zn}, \mathrm{Cu}$ and $\mathrm{Ni}$ to the soil. It was reported by Fristak et al. [44] that $P$ from sewage sludge during pyrolysis was converted into more stable, less available forms such as $\mathrm{Mg}$ or Ca minerals and thus created a more permanent nutrient pool for long term effects. Also, Yuan at al. [67] showed that biochar derived from sewage sludge produced at $700{ }^{\circ} \mathrm{C}$, reduced soil leaching of $\mathrm{NH}_{4}^{-},+, \mathrm{NO}_{3}^{-}, \mathrm{PO}_{4}{ }^{3-}$, and $\mathrm{K}^{+}$.

\section{Conclusions}

Dried biological sludge mixed with spruce wood chips at a ratio of $50 / 50$ by weight was pyrolysed at $700{ }^{\circ} \mathrm{C}$ with the feeding rate varying from 77 to $90 \mathrm{~kg} / \mathrm{h}$. The amount of raw pyrolysis gas generated varied from 390 to $530 \mathrm{~m}^{3} /$ tonne of dry feedstock with calorific values between 12 and $16 \mathrm{MJ} / \mathrm{m}^{3}$. The content of impurities in the raw gas on a $\mathrm{N}_{2}$ free basis was high at 1000-1300 ppm of $\mathrm{H}_{2} \mathrm{~S}$ and $4500-7300 \mathrm{mg} / \mathrm{Nm}^{3}$ of $\mathrm{NH}_{3}$ while a tar content of $11-13 \mathrm{~g}_{\text {total tar }} \mathrm{Nm}_{\text {dry gas }}^{-3}$ was observed. The pyrolysis gas is suitable for co-combustion in a gas boiler with the de-NOx and de-SOx technology.

The raw pyrolysis gas was conditioned in order to reduce the tar content, and remove $\mathrm{NH}_{3}$ and $\mathrm{H}_{2} \mathrm{~S}$. Since air was used as the reagent gas in the high temperature cracking reactor, a higher volume of the final pyrolysis gas diluted with nitrogen were obtained. The yield of conditioned pyrolysis gas was from 820 to $910 \mathrm{~m}^{3} /$ tonne of dry feedstock with calorific values of 6.9 and $7.7 \mathrm{MJ} / \mathrm{m}^{3}$. The content of impurities in this gas was significantly reduced to $40 \mathrm{ppm}$ for $\mathrm{H}_{2} \mathrm{~S}, 120-170 \mathrm{mg} / \mathrm{Nm}^{3}$ for $\mathrm{NH}_{3}$ and 2.4-7.7 $\mathrm{g}_{\text {total tar }}$ $\mathrm{Nm}^{-3}$ dry gas for tar. However, the maximum permissible content of $\mathrm{NH}_{3}$ for the gas engine used was nevertheless exceeded. Moreover, 4 aromatic ring tar compounds (anthracene, $4 H$-cyclopenta[def]phenanthrene, fluoranthen, pyrene, cyclopenta[cd]pyrene, tetraphene, benz[e]acephenanthrylene, indeno[1,2,3-cd]pyrene) were present in the gas, which are not allowed by the engine manufacturer. The conditioned gas is not suitable for internal combustion engine. A dedicated tar cleaning section is required and the water scrubbing section needs to be optimised or the amount of wood in the mixture should be increased.
From 250 to $320 \mathrm{~kg}$ of pyrolysis char was obtained from a tonne of BS and wood mixture. The carbon content in the char meets the criteria set by the European Biochar Certificate. The quality of the char from sludge and wood mixture is enhanced compared to char from only sludge. In particular it facilitates compliance with biochar certification but also may significantly improve the $\mathrm{N}_{2} \mathrm{O}$ mitigation and $\mathrm{NO}_{3}{ }^{-}$leaching from soils. Other properties of the pyrolysis biochar outlined in the EBC should be measured in order to check if the material could be qualified as biochar.

Acknowledgements This work was supported by the Irish State through funding from the Technology Centres programme-Grant Number TC/2014/0016, and Science Foundation Ireland (Grant Number $16 / \mathrm{SP} / 3829)$.

\section{References}

1. Pankakoski, M., Noicol, R., Kestens, H., Bertsch, R., Coldewey, I., Hannemann, H., Kofoed, B., Carballo, J., Merilainen, V., Hale, N., Israilides, C., Moloney, A.M., Odlum, C., Sorilini, C., Kasai, N., Hiddink, J., Barnett, J.W., Sayler, A.R., Duddleston, W., Van Der Walt, H.S., Brits, T.J.: A survey of the composition, treatment and disposal of sludge from dairy effluent treatment plants. Bull. Int. Dairy Federation 356, 4-34 (2000)

2. Ryan, M.P., Walsh, G.: The Characterisation of dairy waste and the potential of whey for industrial fermentation. In: vol. 2012-WRM-MS-9. Environmental Protection Agency (2016)

3. Kwapinska, M., Leahy, J.J.: Pyrolysis-a way of recovering energy from wastewater sludge from milk processing factories. In: Paper presented at the 5th international conference on sustainable solid waste management, Athens, 21-24 June 2017

4. Petruy, R., Lettinga, G.: Digestion of a milk-fat emulsion. Biores. Technol. 61(2), 141-149 (1997). https://doi.org/10.1016/S0960 -8524(97)00042-4

5. Watkins, M., Hash, D.: Dairy factory wastewaters, their use on land and possible environmental impacts-a mini review. Open Agric. J. 4, 1-9 (2010)

6. Kwapinska, M., Leahy, J.J.: Distribution of ash forming elements during pyrolysis of wastewater treatment sludge from milk processing factories. In: 7th international conference on engineering for waste and biomass valorisation, Prague, Czech Republic, 2-5 July 2018 (2018)

7. Dabrowski, W.: Contents of alkaline cations in sludge from dairy wastewater treatment plant. Ecol. Chem. Eng. 16(10), 1259-1265 (2009)

8. Frąc, M., Jezierska-Tys, S.: Agricultural utilisation of dairy sewage sludge: its effect on enzymatic activity and microorganisms of the soil environment. Afr. J. Microbiol. Res. 5(14), 1755-1762 (2011). https://doi.org/10.5897/AJMR10.707

9. López-Mosquera, M.E., Moirón, C., Carral, E.: Use of dairyindustry sludge as fertiliser for grasslands in northwest Spain: heavy metal levels in the soil and plants. Resourc Conserv Recycl 30(2), 95-109 (2000). https://doi.org/10.1016/S0921 $-3449(00) 00058-6$

10. Dabrowski, W.: Treatment and final utilization of sewage sludge from dairy waste water treatment plants located in Podlaskie province. In: Contemporary Problems of Management and Environmental Protection, vol. 4, pp. 141-151. Department of Land Reclamation and Environmental Management, University of Warmia and Mazury, Olsztyn (2009) 
11. Kwapinska, M., Agar, D.A., Leahy, J.J.: Distribution of ash forming elements during pyrolysis of municipal wastewater sludge and sludge from milk processing factories. In: Paper presented at the 6th international conference on sustainable solid waste management, Naxos, Greece, 13-16 June (2018)

12. Scheltinga, H.M.J.: Hygienic aspects, fertilizing value and potential for animal feed of sludges from dairy effluent treatment in the Netherlands. Session 5. Sludge from dairy effluent treatment plants. State Inspection of Health and Environmental Protection, Arnhem (1978)

13. Fehily Timoney and Company. Code of Good Practices for the Use of Biosolids in Agriculture: Guidelines for Farmers. Fehily Timoney and Company, Dublin (1999)

14. Healy, M.G., Fenton, O., Cummins, E., Clarke, R., Peyton, D., Fleming, G., Wall, D., Morrison, L., Cormican, M.: Health and Water Quality Impacts Arising from Land Spreading of Biosolids. Environmental Protection Agency, Wexford (2017)

15. Frac, M., Jezierska-Tys, S., Oszust, K., Gryta, A., Pastor, M.: Assessment of microbiological and biochemical properties of dairy sewage sludge. Int. J. Environ. Sci. Technol. 14(4), 679688 (2017). https://doi.org/10.1007/s13762-016-1179-9

16. Oszust, K., Frac, M.: Evaluation of microbial community composition of dairy sewage sludge, corn silage, grass straw, and fruit waste biomass for potential use in biogas production or soil enrichment. BioResources (2018). http://ojs.cnr.ncsu.edu/index .php/BioRes/article/view/BioRes_13_3_5740_Oszust_Micro bial_Community_Composition/6186

17. Fenton, O., Ashekuzzaman, S.M., Forrestal, P., Karl, R.: Potential of recycling dairy processing organic residue. Teagasc (2017). https://www.teagasc.ie/media/website/publicatio ns/2017/10-Potential-of-recycling-dairy-processing-organicres idues.pdf

18. O'Shea, A.: Where is the sustainable road leading to?. In: Agri environment conference, Dublin, 5 December 2012, pp. 9-12

19. Xu, C., Lancaster, J.: Treatment of secondury pulp and paper sludge for energy recovery. In: DuBois, E., (ed.) Energy Recovery, pp. 187-212. Nova Science Publishers Inc, New York (2009)

20. Samolada, M.C., Zabaniotou, A.A.: Comparative assessment of municipal sewage sludge incineration, gasification and pyrolysis for a sustainable sludge-to-energy management in Greece. Waste Manag. 34(2), 411-420 (2014). https://doi.org/10.1016/j.wasma n.2013.11.003

21. Syed-Hassan, S.S.A., Wang, Y., Hu, S., Su, S., Xiang, J.: Thermochemical processing of sewage sludge to energy and fuel: Fundamentals, challenges and considerations. Renew. Sustain. Energy Rev. 80, 888-913 (2017). https://doi.org/10.1016/j. rser.2017.05.262

22. Trinh, T.N., Jensen, P.A., Dam-Johansen, K., Knudsen, N.O., Sørensen, H.R.: Influence of the pyrolysis temperature on sewage sludge product distribution, bio-oil, and char properties. Energy Fuels. 27(3), 1419-1427 (2013). https://doi.org/10.1021/ef301 944r

23. Capodaglio, A.G., Callegari, A., Dondi, D.: Microwave-Induced pyrolysis for production of sustainable biodiesel from waste sludges. Waste Biomass Valoriz. 7(4), 703-709 (2016). https:// doi.org/10.1007/s12649-016-9496-2

24. Li, X., Wang, B., Wu, S., Kong, X., Fang, Y., Liu, J.: Optimizing the conditions for the microwave-assisted pyrolysis of cotton stalk for bio-oil production using response surface methodology. Waste Biomass Valoriz. 8(4), 1361-1369 (2017). https://doi. org/10.1007/s12649-016-9692-0

25. Lam, S.S., Liew, R.K., Cheng, C.K., Rasit, N., Ooi, C.K., Ma, N.L., Ng, J.-H., Lam, W.H., Chong, C.T., Chase, H.A.: Pyrolysis production of fruit peel biochar for potential use in treatment of palm oil mill effluent. J. Environ. Manag. 213, 400-408 (2018). https://doi.org/10.1016/j.jenvman.2018.02.092
26. Zacharof, M.-P.: Grape winery waste as feedstock for bioconversions: applying the biorefinery concept. Waste Biomass Valoriz. 8(4), 1011-1025 (2017). https://doi.org/10.1007/s1264 9-016-9674-2

27. Liew, R.K., Nam, W.L., Chong, M.Y., Phang, X.Y., Su, M.H., Yek, P.N.Y., Ma, N.L., Cheng, C.K., Chong, C.T., Lam, S.S.: Oil palm waste: an abundant and promising feedstock for microwave pyrolysis conversion into good quality biochar with potential multi-applications. Process Saf. Environ. Prot. 115, 57-69 (2018). https://doi.org/10.1016/j.psep.2017.10.005

28. Maroušek, J., Hašková, S., Zeman, R., Váchal, J., Vaníčková, R.: Processing of residues from biogas plants for energy purposes. Clean Technol. Environ. Policy. 17(3), 797-801 (2015). https:// doi.org/10.1007/s10098-014-0866-9

29. Nam, W.L., Phang, X.Y., Su, M.H., Liew, R.K., Ma, N.L., Rosli, M.H.N.B., Lam, S.S.: Production of bio-fertilizer from microwave vacuum pyrolysis of palm kernel shell for cultivation of Oyster mushroom (Pleurotus ostreatus). Sci. Total Environ. 624, 9-16 (2018). https://doi.org/10.1016/j.scitotenv.2017.12.108

30. Ashekuzzaman, S.M., Kwapinska M., Leahy, J.J., Richards, K., Fenton, O.: Dairy processing sludge feedstock-based biochars for the removal of phosphorus in discharge effluents. In: Paper presented at the 15th international conference on environmental science and technology, Rhodes, Greece, 31 August to 2 September 2017

31. Lam, S.S., Liew, R.K., Wong, Y.M., Azwar, E., Jusoh, A., Wahi, R.: Activated carbon for catalyst support from microwave pyrolysis of orange peel. Waste Biomass Valoriz. 8(6), 2109-2119 (2017). https://doi.org/10.1007/s12649-016-9804-X

32. Severini, F., Leahy, J.J., Kwapinski, W.: Heterogeneous char based solid acid catalysts from brown bin waste to create a green process for the production of butyl butyrate. Waste Biomass Valoriz. 8(7), 2431-2441 (2017). https://doi.org/10.1007/s12649-016-9696-9

33. Zielińska, A., Oleszczuk, P., Charmas, B., Skubiszewska-Zięba, J., Pasieczna-Patkowska, S.: Effect of sewage sludge properties on the biochar characteristic. J. Anal. Appl. Pyrol. 112, 201-213 (2015). https://doi.org/10.1016/j.jaap.2015.01.025

34. Zhang, J., Zuo, W., Tian, Y., Chen, L., Yin, L., Zhang, J.: Sulfur transformation during microwave and conventional pyrolysis of sewage sludge. Environ. Sci. Technol. 51(1), 709-717 (2017). https://doi.org/10.1021/acs.est.6b03784

35. Johansen, J.M., Jakobsen, J.G., Frandsen, F.J., Glarborg, P.: Release of $\mathrm{K}, \mathrm{Cl}$, and $\mathrm{S}$ during pyrolysis and combustion of highchlorine biomass. Energy Fuels. 25(11), 4961-4971 (2011). https ://doi.org/10.1021/ef201098n

36. Hansson, K.-M., Samuelsson, J., Tullin, C., Åmand, L.-E.: Formation of $\mathrm{HNCO}, \mathrm{HCN}$, and $\mathrm{NH}_{3}$ from the pyrolysis of bark and nitrogen-containing model compounds. Combust. Flame. 137(3), 265-277 (2004). https://doi.org/10.1016/j.combustfla me.2004.01.005

37. Lu, H., Zhang, W., Wang, S., Zhuang, L., Yang, Y., Qiu, R.: Characterization of sewage sludge-derived biochars from different feedstocks and pyrolysis temperatures. J. Anal. Appl. Pyrol. 102, 137-143 (2013). https://doi.org/10.1016/j.jaap.2013.03.004

38. Waqas, M., Khan, S., Qing, H., Reid, B.J., Chao, C.: The effects of sewage sludge and sewage sludge biochar on PAHs and potentially toxic element bioaccumulation in Cucumis sativa L. Chemosphere. 105, 53-61 (2014). https://doi.org/10.1016/j.chemospher e.2013.11.064

39. Chen, F., Hu, Y., Dou, X., Chen, D., Dai, X.: Chemical forms of heavy metals in pyrolytic char of heavy metal-implanted sewage sludge and their impacts on leaching behaviors. J. Anal. Appl. Pyrol. 116, 152-160 (2015). https://doi.org/10.1016/j. jaap.2015.09.015

40. Kim, Y., Parker, W.: A technical and economic evaluation of the pyrolysis of sewage sludge for the production of bio-oil. Bioresour. 
Technol. 99(5), 1409-1416 (2008). https://doi.org/10.1016/j.biort ech.2007.01.056

41. Salman, C.A., Schwede, S., Li, H., Thorin, E., Yan, J.: Integrated concept for sludge pyrolysis in waste water treatment plants for biofuel production and nutrients recovery. In: Sludge management in circular economy, Rome 23-25 May 2018

42. Tian, F.-J., Li, B.-Q., Chen, Y., Li, C.-Z.: Formation of NOx precursors during the pyrolysis of coal and biomass. Part V. Pyrolysis of a sewage sludge. Fuel. 81(17), 2203-2208 (2002). https://doi. org/10.1016/S0016-2361(02)00139-4

43. Maroušek, J.: Significant breakthrough in biochar cost reduction. Clean Technol. Environ. Policy. 16(8), 1821-1825 (2014). https ://doi.org/10.1007/s10098-014-0730-y

44. Frišták, V., Piṕška, M., Soja, G.: Pyrolysis treatment of sewage sludge: a promising way to produce phosphorus fertilizer. J. Clean. Prod. 172, 1772-1778 (2018). https://doi.org/10.1016/j. jclepro.2017.12.015

45. Maroušek, J., Kolář, L., Vochozka, M., Stehel, V., Maroušková, A.: Novel method for cultivating beetroot reduces nitrate content. J. Clean. Prod. 168, 60-62 (2017). https://doi.org/10.1016/j.jclep ro.2017.08.233

46. Maroušek, J., Kolár, L., Vochozka, M., Stehel, V., Maroušková, A.: Biochar reduces nitrate level in red beet. Environ. Sci. Pollut. Res. 25(18), 18200-18203 (2018). https://doi.org/10.1007/s1135 6-018-2329-z

47. Horvat, A., Kwapinska, M., Xue, G., Dooley, S., Kwapinski, W., Leahy, J.J.: Detailed measurement uncertainty analysis of solid-phase adsorption-total gas chromatography (gc)-detectable tar from biomass gasification. Energy Fuels. 30(3), 2187-2197 (2016). https://doi.org/10.1021/acs.energyfuels.5b02579

48. Sunooj, K.V., George, J., Kumar, S., Radhakrishna, V.A., Bawa, K.: A.S.: Thermal degradation and decomposition kinetics of freeze dried cow and camel milk as well as their constituents. J. Food Sci. Eng. 1, 77-84 (2011)

49. Mocanu, A.M., Moldoveanu, C., Odochian, L., Paius, C.M., Apostolescu, N., Neculau, R.: Study on the thermal behavior of casein under nitrogen and air atmosphere by means of the TG-FTIR technique. Thermochim. Acta. 546, 120-126 (2012). https://doi. org/10.1016/j.tca.2012.07.031

50. Yang, H., Yan, R., Chen, H., Lee, D.H., Zheng, C.: Characteristics of hemicellulose, cellulose and lignin pyrolysis. Fuel. 86(12), 1781-1788 (2007). https://doi.org/10.1016/j.fuel.2006.12.013

51. Deng, J., Wang, G., Kuang, J., Zhang, Y., Luo, Y.: Pretreatment of agricultural residues for co-gasification via torrefaction. J. Anal. Appl. Pyrol. 86(2), 331-337 (2009). https://doi.org/10.1016/j. jaap.2009.08.006

52. Agegnehu, G., Bass, A.M., Nelson, P.N., Bird, M.I.: Benefits of biochar, compost and biochar-compost for soil quality, maize yield and greenhouse gas emissions in a tropical agricultural soil. Sci. Total Environ. 543, 295-306 (2016). https://doi. org/10.1016/j.scitotenv.2015.11.054

53. European Biochar Foundation (EBC): European Biochar Certificate-Guidelines for a Sustainable Production of Biochar. European Biochar Foundation (EBC), Arbaz (2012)

54. Morf, P., Hasler, P., Nussbaumer, T.: Mechanisms and kinetics of homogeneous secondary reactions of tar from continuous pyrolysis of wood chips. Fuel. 81(7), 843-853 (2002). https:// doi.org/10.1016/S0016-2361(01)00216-2
55. Boroson, M.L., Howard, J.B., Longwell, J.P., Peters, W.A.: Heterogeneous cracking of wood pyrolysis tars over fresh wood char surfaces. Energy Fuels. 3(6), 735-740 (1989). https://doi. org/10.1021/ef00018a014

56. Taralas, G., Vassilatos, V., Sjorstrom, K., Delgado J.: Thermal and catalytic cracking of n-heptane in presence of $\mathrm{CaO}, \mathrm{MgO}$ and calcined dolomites. Can. J. Chem. Eng. 69, 1413-1419 (1991)

57. Lepez, O., Grochowska, A., Malinowski, A., Stolarek, P., Ledakowicz, S.: Thermal treatment of sewage sludge by integrated processes of drying and pyrolysis in a pilot bench scale. In: European meeting on chemical industry and environment, Tarragona, 10-12 June 2015

58. Aznar, M., Anselmo, M.S., Manyà, J.J., Murillo, M.B.: Experimental study examining the evolution of nitrogen compounds during the gasification of dried sewage sludge. Energy Fuels. 23(6), 3236-3245 (2009). https://doi.org/10.1021/ef801108s

59. Fonts, I., Azuara, M., Gea, G., Murillo, M.B.: Study of the pyrolysis liquids obtained from different sewage sludge. J. Anal. Appl. Pyrol. 85(1/2), 184-191 (2009). https://doi.org/10.1016/j. jaap.2008.11.003

60. Domínguez, A., Menéndez, J.A., Inguanzo, M., Pís, J.J.: Production of bio-fuels by high temperature pyrolysis of sewage sludge using conventional and microwave heating. Bioresour. Technol. 97(10), 1185-1193 (2006). https://doi.org/10.1016/j.biort ech.2005.05.011

61. Milne, T.A., Evans, R.J.: Biomass gasifier tars: their nature, formation and conversion. In: vol. NREL/TP-570-25357. (1998)

62. Dresser-Rand: Fuel gas specifications—-synthesis gas (Syngas); IC-G-D30-004e (2016)

63. Wei, L., Wen, L., Yang, T., Zhang, N.: Nitrogen transformation during sewage sludge pyrolysis. Energy Fuels. 29(8), 5088-5094 (2015). https://doi.org/10.1021/acs.energyfuels.5b00792

64. Smetanova, A., Dotterweich, M., Dielh, D., Ulrich, U., Dotterweich N.F.: Influence of biochar and terra preta substances on wettability and erodibility of soils. Zeitschrift fur Geomorphologie 57, 111-134 (2013)

65. Novak, J.M., Watts, D.W.: Augmenting soil water storage using uncharred switchgrass and pyrolyzed biochars. Soil Use Manag. 29(1), 98-104 (2013). https://doi.org/10.1111/sum.12026 doi

66. Borchard, N., Schirrmann, M., Cayuela, M.L., Kammann, C., Wrage-Mönnig, N., Estavillo, J.M., Fuertes-Mendizábal, T., Sigua, G., Spokas, K., Ippolito, J.A., Novak, J.: Biochar, soil and land-use interactions that reduce nitrate leaching and $\mathrm{N} 2 \mathrm{O}$ emissions: a meta-analysis. Sci. Total Environ. 651, 2354-2364 (2019). https://doi.org/10.1016/j.scitotenv.2018.10.060

67. Yuan, H., Lu, T., Wang, Y., Chen, Y., Lei, T.: Sewage sludge biochar: nutrient composition and its effect on the leaching of soil nutrients. Geoderma. 267, 17-23 (2016). https://doi.org/10.1016/j. geoderma.2015.12.020

Publisher's Note Springer Nature remains neutral with regard to jurisdictional claims in published maps and institutional affiliations. 